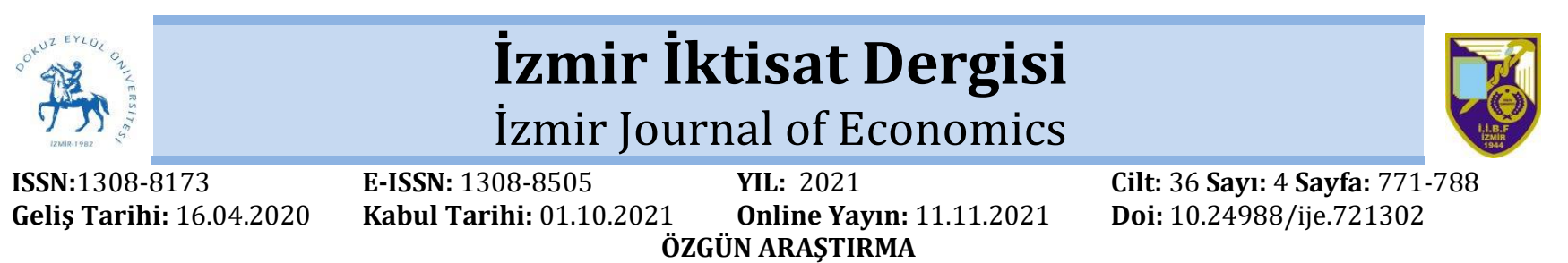

ÖZGÜN ARAŞTIRMA

\title{
Ekonomiyi Harekete Geçiren Kilit Sektörler Nelerdir? Türkiye Üzerine Bir Girdi-Çıktı Analizi
}

\author{
Ersin YENISU1
}

\begin{abstract}
Özet
Bu çalışmada Leontief tarafından 1950'li yıllarda geliştirilen girdi-çıktı yöntemi kullanılmıştır. Yöntem ekonomideki kilit sektörleri tespit etmek amacıyla Türkiye'nin TÜİK tarafından yayınlanan en son tablosu olan 2012 yılı girdi-çıktı tablosuna uygulanmıştır. Elde edilen bulgular şöyledir: I) Türkiye'de on temel sektör içerisinde "İmalat Sanayi" ve "Enerji" sektörleri kilit sektörlerdir. II) Üretimdeki artıșın çalıșanlara yapılan ödemelere etkisi açısından ilk iki sektör "Hizmetler" ve "Ticaret" sektörleridir. III) Sektörlerdeki büyümenin vergi yaratabilme kapasitesi açısından ilk üç sektör "Ulaştırma", "Enerji" ve "Imalat Sanayi" sektörleridir. IV) En fazla ithal girdi kullanım oranına sahip sektörler "Madencilik", "Enerji" ve "İmalat Sanayi" sektörleridir. V) Gayri safi katma değer oluşturabilme açısından tüm sektörler birbirlerine yakın oranlara sahiptir.
\end{abstract}

Anahtar kelimeler: Ekonomik Yapı Analizi, Kilit Sektörler, Girdi-Çıktı Analizi Jel Kodu: C67, E23, 011

\section{What Are The Key Sectors That Moves The Economy? An Input-Output Analysis On Turkey}

\begin{abstract}
In this study, the input-output analysis developed by Leontief in the 1950s was used. The method was applied to 2012 inputoutput table (Turkey's the latest table published by TURKSTAT) in order to identify key sectors in the economy. The findings are as follows: I) In Turkey, "Manufacturing Industry" and "Energy" sector are key sectors. II) In terms of the effect of the increase in production on the payments made to the employees, the first two sectors are the "Services" and "Trade" sectors. III) In terms of the tax-generating capacity of the growth in the sectors, the first three sectors are the "Transportation", "Energy" and "Manufacturing Industry" sectors. IV) The "Mining", "Energy" and "Manufacturing Industry" sectors are the sectors with the highest import input usage rate. V) The gross value added creation rates of all sectors are close to each other.
\end{abstract}

Keywords: Economic Structure Analysis, Key Sectors, Input-Output Analysis Jel Codes: C67, E23, 011

\section{GİRIş}

Ekonomi bilimi sosyal bilimlerin temelidir. Gerek toplumlar gerekse bireyler için ekonomik yaklaşımlar yaşamsal önem taşımaktadır. Geçmişten günümüze ekonomik yapıyı ve ekonomik ilişkilerdeki eğilimleri açıklamak üzere sayısız teori geliștirilmiştir. $\mathrm{Bu}$ teorilerin birçoğu felsefi ya da nitel bir özelliğe sahiptir. Bununla birlikte matematiğin bilime yani hayatımıza kattığı nesnellik bir sosyal bilim olan ekonomiye de sirayet etmiștir. 1950'li yıllarda geliştirilen ve günümüze kadar sürekli ilerleme gösteren girdi-çıktı analizi de söz konusu nicel (kantitatif) yöntemlerden biridir. Ekonominin yapısal özelliklerini ampirik bir yöntemle açıklamaya çalışan girdi-çıktı analizi bir anlamda ulusal ekonomideki ya da ele alınan sektördeki bağlantıları açıklayarak mal veya

ATIF ÖNERİsí (APA): Yenisu, E. (2021). Ekonomiyi Harekete Geçiren Kilit Sektörler Nelerdir? Türkiye Üzerine Bir Girdi-Çıktı Analizi. İzmir İktisat Dergisi, 36(4), 771-788. Doi: 10.24988/ije.721302

${ }^{1}$ Doktora Öğrencisi, Nevşehir Hacı Bektaş Veli Üniversitesi Sosyal Bilimler Enstitüsü İşletme Doktora Programı, NEVŞEHIR. EMAIL: ersinyenisu@gmail.com, ORCID: 0000-0002-0235-4270 


\section{E. YENISU}

hizmet akıșının tanımlanmasına olanak vermektedir.

Girdi-çıktı analizi oldukça kapsamlı ve detaylı bir yöntemdir. Literatürde aynı temel düşünceden yola çıkılarak çok farklı amaçlar için kullanıldığı görülen bu yöntemle yanıt aranabilecek sorulardan bazıları şöyledir: Ekonomiyi harekete geçiren kilit sektörler nelerdir? Belirli bir zaman diliminde ulusal ekonomi yapısal bir dönüşüm geçirmiş midir? Üretimde ithal girdi yoğunluğu artmakta mıdır yoksa azalmakta mıdır? Belirli bir sektörün ulusal ekonomi için önemi nedir?... Kısacası Leontief (1906-1999) tarafından literatüre kazandırılan girdi-çıtı yöntemi uygulamacılara ekonomi yönetimi için son derece önemli ve somut bilgiler sunabilmektedir.

Sonraki araştırmalar için metodolojik temeli detaylı olarak açıklamak suretiyle de bir uygulamayla pratik sonuçlara ulaşabilen bu çalışma bu yönüyle özgün bir incelemedir.

Türkiye ekonomisi örneğini girdi-çıktı yöntemiyle analiz etmeyi amaçlayan bu çalışma beş bölümden oluşmaktadır. Çalışmada giriş bölümünün ardından ikinci bölümde yerli ve yabancı literatürden örnekler sunulmuştur. İzleyen bölüm olan üçüncü bölümde çalışmada kullanılan veriler ve yöntem açıklanmaya çalışılmıştır. Bir sonraki bölümdeyse analizler yapılmış ve bulgular raporlanmıştır. Beșinci ve son bölümde çalışmada elde edilen sonuç özetlenmiş ve öneriler değerlendirilmiştir.

\section{LİTERATÜR TARAMASI}

Yerli ve yabancı literatürde girdi-çıktı yöntemini kullanarak veri analizi yapan çok sayıda çalışma vardır. Bu çalışmaların bir kısmı bu çalışmada olduğu gibi ulusal ekonomilerin temel sektörleri arasındaki ilişkileri analiz etmektedir. Diğer çalışmalar ise bölgeler arası ilişkileri, alt sektörlerin incelenmesini, istihdam ya da gelir çarpanlarının incelenmesini veya belirli bir sektörün ithal girdi yoğunluğunu konu edinen çalışmalardır. Tablo 1'de bahsi geçen literatürden seçilen örneklerin bulguları veya sonuçları özetlenmeye çalıșılacaktır.

Tablo 1: Türkçe ve Yabancı Literatürde Girdi-Çıktı Yöntemini Kullanan Çalışmalardan Örnekler

\begin{tabular}{|c|c|c|c|c|}
\hline $\begin{array}{l}\text { Yazar } \\
\text { (Tarih) }\end{array}$ & Ülke & Çalışmanın Amacı & $\begin{array}{c}\begin{array}{c}\text { Kullanılan Tablo } \\
\text { (Veri) }\end{array} \\
\end{array}$ & Bulgular \\
\hline Özdil (1993) & Türkiye & $\begin{array}{l}\text { Ekonominin tarım, sanayi ve } \\
\text { hizmetler ana sektörleri } \\
\text { bağlamında } \\
\text { değişimini incelemek. }\end{array}$ & $\begin{array}{l}\text { TÜIK - 1963, } 1973 \text { ve } 1985 \\
\text { Girdi-Çıktı Tabloları }\end{array}$ & $\begin{array}{l}\text { Türkiye'de planlı dönemde sanayileşme yönlü yapısal } \\
\text { değişim tezinin geçerli olduğu bulgulanmıştır. }\end{array}$ \\
\hline $\begin{array}{l}\text { Bon, Birgönül } \\
\text { ve Özdoğan } \\
\text { (1999) }\end{array}$ & Türkiye & $\begin{array}{l}\text { İnşaat sektöründeki yapısal } \\
\text { değişimleri ölçmek. }\end{array}$ & $\begin{array}{l}\text { TÜİK - 1973, 1979,1985 ve } \\
1990 \text { Girdi-Çıktı Tabloları }\end{array}$ & $\begin{array}{l}\text { 1973-1990 döneminde inşaat sektörü çarpanları durağan } \\
\text { görünümdedir ve sektör gelişmiş ülkelerdekine benzer } \\
\text { şekilde olgunluk düzeyindedir. }\end{array}$ \\
\hline $\begin{array}{l}\text { Berument ve } \\
\text { Taşçı (2002) }\end{array}$ & Türkiye & $\begin{array}{l}\text { Ham petrol fiyatlarının } \\
\text { Türkiye'de enflasyona neden } \\
\text { olup olmadığını incelemek. }\end{array}$ & $\begin{array}{l}\text { TÜîK - } 1990 \text { Girdi-Çıktı } \\
\text { Tablosu }\end{array}$ & $\begin{array}{l}\text { Petrol fiyatları enflasyonun nedenidir ve bazen } \\
\text { hiperenflasyona yol açabilmektedir. }\end{array}$ \\
\hline $\begin{array}{l}\text { Özkan, Akçaöz } \\
\text { ve Fert (2004) }\end{array}$ & Türkiye & $\begin{array}{l}\text { Türkiye'de } \quad \text { tarımda } \\
\text { kullanılan enerjiyi } \begin{array}{l}\text { analiz } \\
\text { etmek. }\end{array}\end{array}$ & $\begin{array}{l}\text { TÜİK - 1975, 1980, 1985, } \\
\text { 1990, } 1995 \text { ve } 2000 \text { Girdi- } \\
\text { Çıktı Tabloları }\end{array}$ & $\begin{array}{l}\text { Tarımsal üretimde birim ürün başına kullanılan enerji } \\
\text { miktarı artmıştır. Bu nedenle enerji verimliliği için tedbir } \\
\text { alınmalıdır. }\end{array}$ \\
\hline $\begin{array}{l}\text { Çondur ve } \\
\text { Evlimoğlu } \\
\text { (2007) }\end{array}$ & Türkiye & $\begin{array}{l}\text { Madencilik sektörünü girdi- } \\
\text { çıtı yöntemiyle analiz etmek. }\end{array}$ & $\begin{array}{l}\text { TÜİK - } 1996 \text { Girdi-Çıktı } \\
\text { Tablosu }\end{array}$ & $\begin{array}{l}\text { "Kok fırını ve rafine edilmiş petrol ürünleri imalatı" sektörü } \\
10 \text { madencilik alt sektörü içinde kilit sektördür. }\end{array}$ \\
\hline $\begin{array}{l}\text { Ersungur ve } \\
\text { Kizlltan } \\
\text { (2007) }\end{array}$ & Türkiye & $\begin{array}{lr}\text { Türkiye'de } & \text { ithalata } \\
\text { bağımlılığı } & \text { girdi-çıktı } \\
\text { analiziyle incelemek. }\end{array}$ & $\begin{array}{l}\text { TÜík - 1973-1998 Girdi- } \\
\text { Çıktı Tabloları }\end{array}$ & Özellikle imalat sanayinde ithal girdi bağımlılığı artmaktadır. \\
\hline $\begin{array}{l}\text { Kofoworola ve } \\
\text { Gheewala } \\
\text { (2008) }\end{array}$ & Tayland & $\begin{array}{l}\text { İnşaat sektörünün } \\
\begin{array}{l}\text { Tayland } \\
\text { ekonomisine }\end{array} \text { katkısını } \\
\text { ölçmek. }\end{array}$ & $\begin{array}{l}1995 \text { ve } 2000 \text { Girdi-Çıktı } \\
\text { Tabloları }\end{array}$ & $\begin{array}{l}\text { İnşaat sektörü Tayland ekonomisine önemli bir katkı } \\
\text { sağlamaktadır. }\end{array}$ \\
\hline
\end{tabular}


Tablo 1: Türkçe ve Yabancı Literatürde Girdi-Çıktı Yöntemini Kullanan Çalışmalardan Örnekler (Devami)

\begin{tabular}{|c|c|c|c|c|}
\hline $\begin{array}{l}\text { Yazar } \\
\text { (Tarih) }\end{array}$ & Ülke & Çalışmanın Amacı & $\begin{array}{l}\begin{array}{c}\text { Kullanılan Tablo } \\
\text { (Veri) }\end{array} \\
\end{array}$ & Bulgular \\
\hline Yllanci (2008) & Türkiye & $\begin{array}{l}\text { Türkiye için kilit sektörü } \\
\text { tespit etmek. }\end{array}$ & $\begin{array}{l}\text { TÜiK - } 1998 \text { Girdi-Çıłtı } \\
\text { Tablosu }\end{array}$ & $\begin{array}{l}\text { Tarım, ticaret, ulaşım-haberleşme ve kişisel hizmet sektörleri } \\
\text { Türkiye için kilit sektörlerdir. }\end{array}$ \\
\hline $\begin{array}{l}\text { Surugiu, Frent } \\
\text { ve Suruglu } \\
\text { (2009) }\end{array}$ & $\begin{array}{c}\text { Romany } \\
\text { a }\end{array}$ & $\begin{array}{l}\text { Turizmin Romanya } \\
\text { ekonomisine katkısını tespit } \\
\text { etmek. }\end{array}$ & 2005 Girdi-Çıktı Tablosu & $\begin{array}{l}\text { Turizm sektörü Romanya ekonomisi için lokomotif } \\
\text { sektörlerdendir. }\end{array}$ \\
\hline $\begin{array}{l}\text { Bekhet ve } \\
\text { Abdullah } \\
\text { (2010) }\end{array}$ & Malezya & $\begin{array}{l}\text { Tarım sektöründe kullanılan } \\
\text { enerjiyi incelemek. }\end{array}$ & $\begin{array}{l}\text { 1991-2000 } \\
\text { Tabloları }\end{array}$ & $\begin{array}{l}\text { Tarım sektörü ile enerji sektörü arasında zayıf bir bağ vardır. } \\
\text { Fakat anılan dönem itibariyle tarımda kullanılan enerji oranı } \\
\text { artmıştır. }\end{array}$ \\
\hline Atan (2011) & Türkiye & $\begin{array}{l}\text { Sektörel bağlantı yapısını ara } \\
\text { girdilerin menşei (yurtiçi } \\
\text { üretim ve ithal girdi) } \\
\text { açısından analiz etmek. }\end{array}$ & $\begin{array}{l}\text { TÜIK - } 2002 \text { Girdi-Çıłtı } \\
\text { Tablosu }\end{array}$ & $\begin{array}{l}\text { Türkiye'de imalat sanayi sektörü hemen hemen her durumda } \\
\text { kilit sektördür. }\end{array}$ \\
\hline $\begin{array}{l}\text { Çalıșkan ve } \\
\text { Aydoğuş } \\
\text { (2011) }\end{array}$ & Türkiye & $\begin{array}{lr}\text { Türkiye'de } & \text { endüstriyel } \\
\text { büyümenin } & \text { kaynaklarını } \\
\text { tespit etmek. } & \end{array}$ & $\begin{array}{l}\text { TÜİK - 1985, } 1990 \text { ve } 2002 \\
\text { Girdi-Çıktı Tabloları }\end{array}$ & $\begin{array}{l}\text { Türkiye'nin } 1980 \text { sonrası dışa açık sanayileşme politkaları } \\
\text { sadece uzun dönemde etkilidir ve bu dönemde ithalata } \\
\text { bağımlıllk artmıştır. }\end{array}$ \\
\hline $\begin{array}{l}\text { Gündeş } \\
\text { (2011) }\end{array}$ & Türkiye & $\begin{array}{l}\text { Türkiye'de inşaat sektörünün } \\
\text { gelişimini incelemek. }\end{array}$ & $\begin{array}{l}\text { 1969-2006 } \\
\text { Tabloları }\end{array}$ & $\begin{array}{l}\text { İnşaat sektörü anılan dönemde giderek ekonominin } \\
\text { sürükleyicisi olma niteliğini kaybetmiştir. }\end{array}$ \\
\hline $\begin{array}{l}\text { Atan ve } \\
\text { Arslantürk } \\
\text { (2012) }\end{array}$ & Türkiye & $\begin{array}{lr}\text { Türkiye'de } & \text { turizm } \\
\text { sektörünün } & \text { ekonomik } \\
\text { büyümeye etkisini incelemek. }\end{array}$ & $\begin{array}{l}\text { TÜíK - } 2002 \text { Girdi-Çıktı } \\
\text { Tablosu }\end{array}$ & $\begin{array}{l}\text { Turizm sektörü kilit sektör değildir. Fakat yüksek geri } \\
\text { bağlantıları nedeniyle ekonomi için önemli bir sektördür. }\end{array}$ \\
\hline $\begin{array}{l}\text { Canlı ve Kaya } \\
(2012)\end{array}$ & Türkiye & $\begin{array}{l}\text { Turizm sektörünün } \\
\text { ekonomideki yeri ve önemini } \\
\text { açıklamak. }\end{array}$ & $\begin{array}{l}\text { TÜiK - } 2002 \text { Girdi-Çıktı } \\
\text { Tablosu }\end{array}$ & $\begin{array}{l}\text { Toplam ileri bağlantı katsayısı ve toplam geri bağlantı } \\
\text { katsayısının yüksek çıkması nedeniyle turizm stratejik bir } \\
\text { sektördür. }\end{array}$ \\
\hline $\begin{array}{l}\text { Özdemir ve } \\
\text { Mercan } \\
(2012)\end{array}$ & Türkiye & $\begin{array}{l}\text { Enerji sektörünün diğer } \\
\text { sektörlerle olan girdi-çıktı } \\
\text { ilişkisini incelemek. }\end{array}$ & $\begin{array}{l}\text { TÜiK - } 2002 \text { Girdi-Çıktı } \\
\text { Tablosu }\end{array}$ & $\begin{array}{l}\text { Enerji sektörü imalat sanayi sektöründen sonra en kilit } \\
\text { sektördür ve söz konusu sektörün önemi giderek } \\
\text { artmaktadır. }\end{array}$ \\
\hline $\begin{array}{l}\text { Gül, Çağatay } \\
\text { ve Taşdoğan } \\
\text { (2014) }\end{array}$ & Türkiye & $\begin{array}{l}\text { Türkiye'de inşaat sektörünün } \\
\text { sürükleyici sektör olup } \\
\text { olmadığını açıklamak. }\end{array}$ & $\begin{array}{l}\text { World Input Output } \\
\text { Database } \quad(2002-2011) \\
\text { Girdi-Çılktı Tabloları }\end{array}$ & $\begin{array}{l}\text { İnşaat sektörü genel ekonomi için önemli bir sektördür. Fakat } \\
\text { politika yapıcıların beklediği kadar etkin bir sektör değildir. }\end{array}$ \\
\hline Ayaş (2016) & Türkiye & $\begin{array}{l}\text { Hizmetler } \\
\text { ekonomiye } \\
\text { incelemek. }\end{array}$ & $\begin{array}{l}\text { World Input Output } \\
\text { Database } \quad(1995-2011) \\
\text { Girdi-Çıktı Tabloları }\end{array}$ & $\begin{array}{l}\text { Hizmetler sektörünün hem üretim (ileri bağlantı) hem de } \\
\text { talep (geri bağlantı) etkileri yüksektir. }\end{array}$ \\
\hline $\begin{array}{l}\text { Gül ve } \\
\text { Cakaloğlu } \\
\text { (2017) }\end{array}$ & $\begin{array}{l}43 \mathrm{AB} \\
\text { Ülkesi }\end{array}$ & $\begin{array}{l}\text { İnşaat sektörü ekonominin } \\
\text { lokomotifi olabilir mi? }\end{array}$ & $\begin{array}{l}\text { World Input-Output } \\
\text { Database (WIOD) 2000- } \\
\text { 2014 Girdi-Çıtı Tabloları } \\
\text { (15 Tablo) }\end{array}$ & $\begin{array}{l}\text { Türkiye'de inşaat sektörünün ekonominin sürükleyicisi } \\
\text { olabilme ihtimali zayıftır. }\end{array}$ \\
\hline
\end{tabular}

Karkacierve Türkiye Türkiye'de tarım, gıda ve TüiK - 2012 Girdi-Çıktı Tarım, enerji ve gıda imalat sanayinin çarpan etkileri Bölük (2017) $\quad$ enerji sektörlerinin yapısal Tablosu $\quad$ yüksektir ve söz konusu sektörler ekonomide anahtar rol analizini gerçekleştirmek. oynamaktadırlar.

\begin{tabular}{|c|c|c|c|c|}
\hline $\begin{array}{l}\text { Uğurlu ve } \\
\text { Tuncer (2017) }\end{array}$ & Türkiye & $\begin{array}{l}\text { Türkiye'de sanayi ve hizmet } \\
\text { sektörlerinin } \quad \text { büyüme ve } \\
\text { istihdama } \\
\text { incelemek. }\end{array}$ & $\begin{array}{l}\text { World Input-Output } \\
\text { Database (WIOD) 1995- } \\
2011 \text { Girdi-Çıktı Tabloları } \\
(17 \text { Tablo) }\end{array}$ & $\begin{array}{l}\text { Türkiye'de imalat sanayi sektörleri kilit sektördür. Bazl } \\
\text { hizmet sektörleri hariç hizmet sektörleri ekonomiyi } \\
\text { hareketlendirmede yetersizdir. }\end{array}$ \\
\hline $\begin{array}{l}\text { Karkacier } \\
(2018)\end{array}$ & $\begin{array}{l}\text { Antalya } \\
\text { (Türkiy } \\
\text { e) }\end{array}$ & $\begin{array}{l}\text { Antalya ilinde tarıma dayalı } \\
\text { sanayide kilit sektörleri } \\
\text { belirlemek. }\end{array}$ & $\begin{array}{l}\text { Anket Tekniği (Girdi-Çılktı } \\
\text { Tablosunu Yazar Kendi } \\
\text { Oluşturmuştur) }\end{array}$ & $\begin{array}{l}\text { Dokuz alt sektörlü analizde "bitkisel üretim" sektörü söz } \\
\text { konusu ilin tarıma dayalı sanayisi için lokomotif sektördür. }\end{array}$ \\
\hline $\begin{array}{l}\text { Maden ve } \\
\text { Ertürk (2019) }\end{array}$ & Türkiye & $\begin{array}{l}\text { Turizm sektörünün Türkiye } \\
\text { ekonomisine etkilerini girdi- } \\
\text { çıktı yöntemiyle incelemek. }\end{array}$ & $\begin{array}{l}\text { TÜİK - } 2012 \text { Girdi-Çıtıtı } \\
\text { Tablosu }\end{array}$ & $\begin{array}{l}\text { Turizm sektörü toplam geri ve ileri bağlantı etkileri açısından } \\
\text { ikinci kilit sektördür ve turizm teşvikleri ekonomiyi } \\
\text { canlandıracaktır. }\end{array}$ \\
\hline $\begin{array}{l}\text { Tok ve Sevinç } \\
\text { (2019) }\end{array}$ & Türkiye & $\begin{array}{l}\text { Türkiye'de üretimin ithal } \\
\text { girdi yoğunluğunu incelemek. }\end{array}$ & $\begin{array}{l}\text { TÜİK - } 2002 \text { ve } 2012 \text { Girdi- } \\
\text { Çıktı Tabloları }\end{array}$ & $\begin{array}{l}\text { Türkiye'de üretimin ithal girdi kullanımı \% 16,1'den (2002) } \\
\% \text { 19,3'e (2012) çıkmıştır. }\end{array}$ \\
\hline
\end{tabular}




\section{KULLANILAN VERİ VE METODOLOJI}

Türkiye İstatistik Kurumu (TÜİK) 1973, 1979, 1985, 1990, 1998, 2002 ve son olarak da 2012 yılı girdi-çıktı tablolarını diğer bir adıyla ekonominin kullanım tablolarını internet sitesinin (http://www.tuik.gov.tr) "Ulusal Hesaplar" başlığı altında yayınlamıştır. Çalışmamızda söz konusu tabloların günümüze en yakın ve 64 alt sektörü içeren 2012 yılı girdi-çıktı tablosu verileri analiz edilmiştir. Çalışmada veri düzenleme ve matris işlemleri gibi matematiksel hesaplamalar için "Microsoft (Excel)" ve cebirsel denklem yazımı için "Mathtype-Equation" programlarından yararlanılmıștır.

Bu çalışma zaman unsurunu dikkate almayan statik bir çalışmadır. Bununla birlikte Türkçe ve yabancı literatürde alt sektörleri farklı yıllar itibariyle karşılaştırmalı olarak girdi-çıtı yöntemiyle ele alan yayınlar da mevcuttur (Çalışkan ve Aydoğuș, 2011; Uğurlu ve Tuncer, 2017; Maden ve Ertürk, 2019).

Girdi-çıktı analizi bir ekonomide alt sektörler arasındaki ilișkileri ortaya koymaktadır. Nobel ödüllü Leontief (1953) tarafından geliștirilen söz konusu analizle ekonomide hangi sektörün "kilit sektör" diğer bir deyişle ekonomiyi harekete geçirecek olan lokomotif sektör olduğu, bir sektörün diğer sektörlere verdiği çıktı oranı diğer bir ifadeyle "İleri Bağlantı Katsayısı (IBBK)" ve yine bir sektörün diğer sektörlerden aldığı girdi oranı yani "Geri Bağlantı Katsayısı (GBK)" hesaplanabilir. Bazı yazarlar ileri bağlantı katsayısını "Üretim Etkisi”, geri bağlantı katsayısını "Talep Etkisi" olarak isimlendirmektedirler. Bununla birlikte literatürde üretimin ithal girdi yoğunluğunu girdi-çıktı analizi yöntemiyle ölçmeyi amaçlayan çalışmalar da mevcuttur (Özcan Tok ve Sevinç, 2019). Kısacası girdi çıktı yöntemiyle ulusal bir ekonomideki sektörler arası ilişkiler saptanabilir. Bu doğrultuda herhangi bir sektördeki bir birimlik üretim artışının ya da o sektöre olan nihai talep artışının çalışanlara yapılan ödemelere etkisi, gayri safi katma değer oluşturma yeteneği, vergi oluşturma kapasitesi ve ithalat üzerindeki etkisi girdi-çıktı analiziyle ölçülebilir.

Diğer bir ifadeyle sayısal yöntemlerin özel bir hali diyebileceğimiz girdi çıktı yöntemi diğer yöntemlere nazaran çok esnek bir yapıya sahiptir. Teorik olmaktan ziyade ampirik bir yöntem olan girdi-çıktı analiziyle ekonominin yapısal durumu hakkında detaylı bilgi edinilebilir (Çondur, 2007; 31). Girdi çıktı analizinin en önemli varsayımı ise üretimde kullanılan girdilerle üretim arasında belli ve sabit bir oranlı ilişkinin olmasıdır. Girdilerle çıktılar arasındaki ilişkinin doğrusal olması genel denge temelli analizin en önemli varsayımıdır denilebilir (Chase vd., 1993; 6).

Girdi-çıktı analizinde ilk olarak satır ve sütunlardan oluşan girdi-çıktı tablosu diğer bir ifadeyle kullanım tablosu (endüstriyel işlemler tablosu) temin edilir. Kullanım tablosunda satırlar girdileri sütunlar da kullanımları göstermektedir. Örneğin (1) numaralı sektörle aynı satırdaki rakam o sütundaki sektöre (1) numaralı sektörden ne kadar girdi verildiğini gösterir. Kullanım tablosundaki alt sektörlerin toplanmasına "toplulaştırma" adı verilir. Örneğin; TÜİK'in 2012 yılı girdi-çıktı tablosunun orijinal halinde 64 alt sektör bulunmaktadır. Bu çalışmada 2012 yılı girdiçıktı tablosu Avrupa Topluluğu Ekonomik Aktivitelerin İstatistiksel Sinıflandırması (NACE) esas alınarak on (10) sektör olarak Tablo 2'deki gibi toplulaştırılmıştır.

Tablo 2: NACE Rev 1.1 ve NACE Rev 2 Sinıflandırmaları Esas Alınarak TÜIK 2012 Girdi-Çıktı Tablosunun Toplulaștırılması

\begin{tabular}{|c|c|c|}
\hline $\begin{array}{c}\text { Sıra } \\
\text { No }\end{array}$ & $\begin{array}{c}\text { Toplulaştırılmıs } \\
\text { Sektörler }\end{array}$ & $\begin{array}{c}\text { TÜíK 2012 Girdi-Çıktı } \\
\text { Tablosu Sektör No }\end{array}$ \\
\hline 1 & Tarım & $1-3$ \\
\hline 2 & Madencilik & 4 \\
\hline 3 & Glda & 5 \\
\hline 4 & İmalat & $6-23$ \\
\hline 5 & Enerji & $24-26$ \\
\hline 6 & İnşaat & 27 \\
\hline 7 & Ticaret & $28-30$ \\
\hline 8 & Ulaștırma & $31-34$ \\
\hline 9 & Turizm & $36,53,59,60$ \\
\hline 10 & Hizmetler & $35,37-52,54-58,61-64$ \\
\hline
\end{tabular}

Kaynak: TÜİK 2012 Girdi-Çıktı Tablosu 
Yukarıdaki tabloda örneğin; kendi tanımlamamı olan "Tarım" sektörünü oluşturan alt sektörler, 2012 girdi-çıktı tablosundaki 1 (Tarım ve avcılık ürünleri ve ilgili hizmetler), 2 (Orman ürünleri ve ilgili hizmetler) ve 3 (Balık ve diğer balıkçlılk ürünleri; su ürünleri; balıkçllı için destekleyici hizmetler) (Bkz. EK 2) alt sektörlerinin satır için dikey ve sütunlar içinse yatay toplamıdır.

Çalışmamız için 10 sektör olarak “Toplulaştırılmış Kullanım Tablosunun (K)" matris gösterimi şöyledir;

$$
\mathrm{K}=\left[\begin{array}{ccccc}
X_{1,1} & X_{1,2} & X_{1,3} & \ldots & X_{1,10} \\
X_{2,1} & X_{2,2} & X_{2,3} & \ldots & X_{2,10} \\
X_{3,1} & X_{3,2} & X_{3,3} & \ldots & X_{3,10} \\
: & : & : & : & : \\
X_{10,1} & X_{10,2} & X_{10,3} & \ldots & X_{10,10}
\end{array}\right]
$$

K matrisindeki değerlerin, bulunduğu sütunun en altındaki üretim değerine (toplam üretim) bölünmesiyle hesaplanan "Girdi Katsayıları Matrisi (A)" şöyle formüle edilebilir.

$$
t_{i j}=\frac{T_{i j}}{T_{j}}
$$

Yukarıdaki gösterimde;

$\mathrm{i}=$ Sektörlerin satır değerlerini, $\mathrm{j}=$ Sektörlerin sütun değerlerini, $t_{i j}=$ İlgili sektörün bir birim üretim yapabilmesi için diğer sektörlerden alması gereken girdi miktarı diğer bir ifadeyle ilgili sektörün girdi katsayısını, $\mathrm{T}_{\mathrm{ij}}=$ Kullanım tablosundaki i. satır ve j. sütundaki değeri, $\mathrm{T}_{\mathrm{j}}=$ Kullanım tablosunda bir sütunun toplam değeri (üretim toplamı) ya da sektörel üretim değeridir. Örneğimizde; $X_{1}, \ldots . ., X_{10}$ üretim toplamı değerleridir.

$$
\mathrm{A}=\left[\begin{array}{ccccc}
\frac{X_{1,1}}{X_{1}} & \frac{X_{1,2}}{X_{2}} & \frac{X_{1,3}}{X_{3}} & \ldots & \frac{X_{1,10}}{X_{10}} \\
\frac{X_{2,1}}{X_{1}} & \frac{X_{2,2}}{X_{2}} & \frac{X_{2,3}}{X_{3}} & \ldots & \frac{X_{2,10}}{X_{10}} \\
\frac{X_{3,1}}{X_{1}} & \frac{X_{3,2}}{X_{2}} & \frac{X_{3,3}}{X_{3}} & \ldots & \frac{X_{3,10}}{X_{10}} \\
: & : & : & : & : \\
\frac{X_{10,1}}{X_{1}} & \frac{X_{10,2}}{X_{2}} & \frac{X_{10,3}}{X_{3}} & \ldots & \frac{X_{10,10}}{X_{10}}
\end{array}\right]
$$

Girdi katsayıları matrisinde (A) herhangi bir sektöre ait satır toplamı diğer sektörlerin söz konusu sektörden ne kadar ara malı talep ettiğini gösteren doğrudan "İleri Bağlantı Katsayısını (IBK)" verir. Girdi katsayıları matrisinin sütun toplamları ise ele alınan sektörün doğrudan “Geri Bağlantı Katsayısını (GBK)" vermektedir. Söz konusu iki katsayının matematiksel gösterimi şöyledir (Canlı ve Kaya, 2012; 5).

$$
\dot{I} B K_{i}=\frac{\sum_{j} T_{i j}}{T_{j}}, G B K_{j}=\frac{\sum_{i} T_{i j}}{T_{j}}
$$

Girdi katsayıları matrisinin (A) satır ve sütun toplamları sektörler arası doğrudan ileri bağlantı ve doğrudan geri bağlantı etkilerini gösterir. Sektörler arası dolaylı etkiyi de taşıyan toplam etkiyi görebilmek içinse "Leontief Ters Matrisi ((I-A)-1)" hesaplanmalıdır.

Leontief ters matrisinin hesaplanabilmesi için öncelikle yukarıda değinilen girdi katsayıları matrisi (A) köşegenleri 1, diğer elemanları 0 olan birim matrisden çlkarılmalıdır. Söz konusu işlemin cebirsel gösterimi şöyledir: 


$$
\mathrm{I}-\mathrm{A}=\left[\begin{array}{ccccc}
1 & 0 & 0 & \ldots & 0 \\
0 & 1 & 0 & \ldots & 0 \\
0 & 0 & 1 & \ldots & 0 \\
: & : & : & : & : \\
0 & 0 & 0 & \ldots & 1
\end{array}\right]-\left[\begin{array}{ccccc}
\frac{X_{1,1}}{X_{1}} & \frac{X_{1,2}}{X_{2}} & \frac{X_{1,3}}{X_{3}} & \ldots & \frac{X_{1,10}}{X_{10}} \\
\frac{X_{2,1}}{X_{1}} & \frac{X_{2,2}}{X_{2}} & \frac{X_{2,3}}{X_{3}} & \ldots & \frac{X_{2,10}}{X_{10}} \\
\frac{X_{3,1}}{X_{1}} & \frac{X_{3,2}}{X_{2}} & \frac{X_{3,3}}{X_{3}} & \ldots & \frac{X_{3,10}}{X_{10}} \\
: & : & : & : & : \\
\frac{X_{10,1}}{X_{1}} & \frac{X_{10,2}}{X_{2}} & \frac{X_{10,3}}{X_{3}} & \ldots & \frac{X_{10,10}}{X_{10}}
\end{array}\right]
$$

Yukarıdaki on satır ve on sütundan $(10 \times 10)$ oluşan (I-A) matrisinin tersi alındığında Leontief ters matrisine ulaşılır.

$$
(\mathrm{I}-\mathrm{A})^{-1}=\left[\begin{array}{ccccc}
a_{1,1} & a_{1,2} & a_{1,3} & \ldots & a_{1,10} \\
a_{2,1} & a_{2,2} & a_{2,3} & \ldots & a_{2,10} \\
a_{3,1} & a_{3,2} & a_{3,3} & \ldots & a_{3,10} \\
: & : & : & : & : \\
a_{10,1} & a_{10,2} & a_{10,3} & \ldots & a_{10,10}
\end{array}\right]
$$

Leontief ters matrisinin satır (yatay) toplamları $\left(a_{1,1}+a_{1,2}+\ldots+a_{1,10}\right)$ "Toplam Íleri Bağlantı Etkisi"ni, sütun (dikey) toplamları ( $\left.a_{1,1}+{ }_{2,1}+\ldots+a_{10,1}\right) \quad$ "Toplam Geri Bağlantı Etkisi"ni verir. Toplam ileri bağlantı etkisi ile toplam geri bağlantı etkisinin toplamı ise o sektörün ekonomiyi harekete geçirebilme kapasitesini diğer bir ifadeyle kilit sektör olabilme özelliğini ortaya çıkarır (Çondur ve Evlimoğlu, 2007; 34-35).

\section{ANALİZ VE BULGULAR}

Girdi-çıktı analizlerinde uygulamada pratiklik ve sektörel ilişkilerin görünümünü netleştirmek amacıyla genellikle toplulaştırma yapılmaktadır. Bu çalışmada da 64 alt sektöre ayrılan TÜİK-2012 girdi-çıktı tablosundan 10 ana sektör belirlenmiş ve yatay/dikey toplamlar alınarak hesaplamalar yapılmıștır. $\mathrm{Bu}$ sektörler orijinal girdi-çıktı tablosunun yapısına uyumlu olarak aşağıdaki şekilde belirlenmiştir:

Tablo 3: Toplulaştırılmış Temel (Ana) Sektörler

\begin{tabular}{|ccccc|}
\hline Tarım & Madencilik & Gıda & İmalat & Enerji \\
$(1)$ & $(2)$ & $(3)$ & $(4)$ & $(5)$ \\
İnşaat & Ticaret & Ulaștırma & Turizm & Hizmetler \\
$(6)$ & $(7)$ & $(8)$ & $(9)$ & $(10)$ \\
\hline
\end{tabular}

Tablo 3'teki sektörler ulusal bir ekonomide temel ya da ana sektörler olarak da tanımlanabilir. Nitekim bu çalışmada Türkiye ekonomisindeki ana sektörler arasındaki ilişkiler açıklanmaya çalışılmıştır. TÜİK-2012 girdi-çıktı tablosundan oluşturulan toplulaştırılmış girdi-çıktı tablosunun orijinal değerleri EK 1'de sunulmuştur. EK 1'de satırdaki değerlerin her biri o sütundaki sektöre satırdaki sektörün verdiği girdi miktarını göstermektedir. Örneğin; 2012 yılında Türkiye'de tarım sektörü gıda sektörüne 56.673.948.000 TL'llk ve enerji sektörü imalat sektörüne 43.418.616.000 TL'lık girdi vermiştir (Bkz. EK 1) Toplulaştırılmış 10 temel (ana) sektörün genel ekonomi içindeki büyüklügü Şekil 1'den görülebilir.

Şekil 1: Türkiye Ekonomisinde 2012 Yılı Temel (Ana) Sektörlerin Üretim Büyüklükleri (Milyar TL Cari Fiyatlarla)

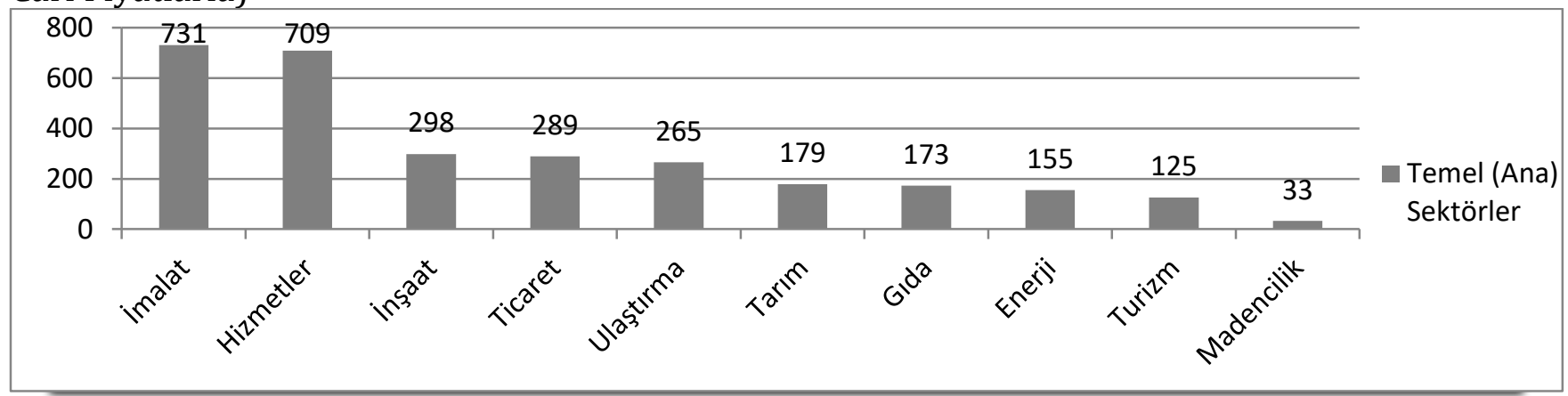

Kaynak: TÜİK 2012 Girdi-Çııtı Tablosu (“Toplam Üretim” Değerleri) 
Şekil 1'e göre 2012 yılında Türkiye'de üretim açısından en büyük sektörler "İmalat" ve "Hizmetler" sektörleridir. Yukarıdaki grafiğe bakılırsa çalışmanın bundan sonraki kısmında özellikle bu iki öncü sektörün dikkatle değerlendirilmesi gereklidir.

Toplulaştırma ve sektörlerin göreceli büyüklüklükleri belirlendikten sonra girdiçıktı yönteminin uygulama aşamalarına geçilebilir. Sektörler arası doğrudan ilişkileri gözlemleyebilmek amacıyla toplulaştırılmış girdi-çıktı tablosundan (K) girdi katsayıları tablosu (A) oluşturulmuştur. Bu dönüşüm toplulaştırılmış girdi-çıktı tablosundaki her bir değerin bulunduğu sütunun (ya da sektörün) en altındaki üretim toplamı değerine bölünerek gerçekleştirilmiştir. Girdi katsayıları matrisi sektörler arası karşılaştırma olanaklarını arttırmaktadır.

Buna göre 0,7109 toplam değeriyle "Enerji" sektörü tüm sektörler içerisinde kendinden önceki sektörleri en fazla harekete geçiren sektördür.
Nitekim enerji sektöründe üretimdeki bir birimlik artış diğer sektörleri yaklaşık 0,7109 birim üretime teşvik etmektedir.

Diğer bir ifadeyle enerji sektöründe bir birimlik üretim artışı gerçekleştirebilmek için ekonominin diğer sektörlerinden 0,7109 birim girdi alınmaktadır. Girdi katsayıları matrisine göre

ileri bağlantı katsayısı en yüksek olan sektör ise "İmalat" sektörüdür. İmalat sektöründe bir birimlik üretim artışıyla diğer (sonraki) sektörlere yaklaşık 1,3374 birim girdi sunulmaktadır.

Girdi katsayıları matrisine çeşitli matris işlemleri uygulanarak ekonomideki doğrudan ve dolaylı etkileri gösteren "Leontief Ters Matrisi"ne ulaşlabilir. Leontief ters matrisi ile lokomotif diğer bir ifadeyle ekonomiyi hareket geçiren temel sektörler belirlenir.

Aşağıdaki gibi hesaplanan (I-A) matrisinin tersi alındığında üçüncü gösterimdeki Leontief ters matrisine $\left((\mathrm{I}-\mathrm{A})^{-1}\right)$ ulaşılır.

\begin{tabular}{lccccccccccc}
\hline & $(1)$ & $(2)$ & $(3)$ & $(4)$ & $(5)$ & $(6)$ & $(7)$ & $(8)$ & \multicolumn{1}{c}{$(9)$} & $(10)$ & Toplam \\
\hline Tarım (1) & 0,1647 & 0,0041 & 0,3271 & 0,0116 & 0,0001 & 0,0004 & 0,0007 & 0,0001 & 0,0289 & 0,0024 & 0,5398 \\
Madencilik (2) & 0,0025 & 0,0595 & 0,0048 & 0,0745 & 0,1825 & 0,0165 & 0,0034 & 0,0016 & 0,0012 & 0,0034 & 0,3498 \\
Gida (3) & 0,0356 & 0,0011 & 0,1376 & 0,0015 & 0,0004 & 0,0004 & 0,0058 & 0,0007 & 0,1396 & 0,0041 & 0,3268 \\
İmalat (4) & 0,0822 & 0,1330 & 0,0660 & 0,4027 & 0,0208 & 0,3091 & 0,0794 & 0,1370 & 0,0409 & 0,0665 & $\mathbf{1 , 3 3 7 4}$ \\
Enerji (5) & 0,0081 & 0,0301 & 0,0116 & 0,0594 & 0,4307 & 0,0019 & 0,0160 & 0,0030 & 0,0233 & 0,0169 & 0,6010 \\
İşaat (6) & 0,0020 & 0,0028 & 0,0020 & 0,0021 & 0,0167 & 0,1586 & 0,0099 & 0,0016 & 0,0107 & 0,0141 & 0,2206 \\
Ticaret (7) & 0,0283 & 0,0361 & 0,0714 & 0,0541 & 0,0086 & 0,0467 & 0,1896 & 0,0521 & 0,0361 & 0,0169 & 0,5399 \\
Ulaștırma (8) & 0,0148 & 0,0599 & 0,0443 & 0,0350 & 0,0079 & 0,0202 & 0,0563 & 0,2128 & 0,0306 & 0,0163 & 0,4982 \\
Turizm (9) & 0,0001 & 0,0025 & 0,0017 & 0,0023 & 0,0008 & 0,0013 & 0,0097 & 0,0034 & 0,0705 & 0,0072 & 0,0995 \\
Hizmetler (10) & 0,0078 & 0,0529 & 0,0337 & 0,0415 & 0,0423 & 0,0511 & 0,1718 & 0,0502 & 0,1036 & 0,1507 & 0,7057 \\
\hline Toplam & 0,3463 & 0,3819 & 0,7002 & 0,6845 & $\mathbf{0 , 7 1 0 9}$ & 0,6062 & 0,5426 & 0,4625 & 0,4853 & 0,2984 & \\
\hline
\end{tabular}

\begin{tabular}{llccccccccc}
\hline & \multicolumn{1}{c}{$(1)$} & $(2)$ & $(3)$ & $(4)$ & $(5)$ & $(6)$ & $(7)$ & $(8)$ & $(9)$ & $(10)$ \\
\hline Tarım (1) & 0,8353 & $-0,0041$ & $-0,3271$ & $-0,0116$ & $-0,0001$ & $-0,0004$ & $-0,0007$ & $-0,0001$ & $-0,0289$ & $-0,0024$ \\
Madencilik (2) & $-0,0025$ & 0,9405 & $-0,0048$ & $-0,0745$ & $-0,1825$ & $-0,0165$ & $-0,0034$ & $-0,0016$ & $-0,0012$ & $-0,0034$ \\
Gida (3) & $-0,0356$ & $-0,0011$ & 0,8624 & $-0,0015$ & $-0,0004$ & $-0,0004$ & $-0,0058$ & $-0,0007$ & $-0,1396$ & $-0,0041$ \\
İmalat (4) & $-0,0822$ & $-0,1330$ & $-0,0660$ & 0,5973 & $-0,0208$ & $-0,3091$ & $-0,0794$ & $-0,1370$ & $-0,0409$ & $-0,0665$ \\
Enerji (5) & $-0,0081$ & $-0,0301$ & $-0,0116$ & $-0,0594$ & 0,5693 & $-0,0019$ & $-0,0160$ & $-0,0030$ & $-0,0233$ & $-0,0169$ \\
İnsaat (6) & $-0,0020$ & $-0,0028$ & $-0,0020$ & $-0,0021$ & $-0,0167$ & 0,8414 & $-0,0099$ & $-0,0016$ & $-0,0107$ & $-0,0141$ \\
Ticaret (7) & $-0,0283$ & $-0,0361$ & $-0,0714$ & $-0,0541$ & $-0,0086$ & $-0,0467$ & 0,8104 & $-0,0521$ & $-0,0361$ & $-0,0169$ \\
Ulaștırma (8) & $-0,0148$ & $-0,0599$ & $-0,0443$ & $-0,0350$ & $-0,0079$ & $-0,0202$ & $-0,0563$ & 0,7872 & $-0,0306$ & $-0,0163$ \\
Turizm (9) & $-0,0001$ & $-0,0025$ & $-0,0017$ & $-0,0023$ & $-0,0008$ & $-0,0013$ & $-0,0097$ & $-0,0034$ & 0,9295 & $-0,0072$ \\
Hizmetler (10) & $-0,0078$ & $-0,0529$ & $-0,0337$ & $-0,0415$ & $-0,0423$ & $-0,0511$ & $-0,1718$ & $-0,0502$ & $-0,1036$ & 0,8493 \\
\hline
\end{tabular}




\section{E. YENISU}

\begin{tabular}{|c|c|c|c|c|c|c|c|c|c|c|c|c|}
\hline & & (1) & (2) & (3) & (4) & (5) & (6) & (7) & (8) & (9) & $(10)$ & Toplam \\
\hline \multirow{11}{*}{$(\mathrm{I}-\mathrm{A})^{-1}=$} & Tarım (1) & 1,2208 & 0,0121 & 0,4674 & 0,0296 & 0,0070 & 0,0135 & 0,0116 & 0,0076 & 0,1115 & 0,0097 & 1,8907 \\
\hline & Madencilik (2) & 0,0295 & 1,1074 & 0,0434 & 0,1840 & 0,3681 & 0,0953 & 0,0410 & 0,0406 & 0,0335 & 0,0298 & 1,9726 \\
\hline & Gida (3) & 0,0519 & 0,0047 & 1,1819 & 0,0078 & 0,0040 & 0,0052 & 0,0138 & 0,0047 & 0,1812 & 0,0086 & 1,4637 \\
\hline & İmalat (4) & 0,2091 & 0,3057 & 0,2686 & 1,7958 & 0,2061 & 0,6995 & 0,2546 & 0,3443 & 0,1799 & 0,1725 & 4,4362 \\
\hline & Enerji (5) & 0,0454 & 0,0972 & 0,0693 & 0,2071 & 1,8042 & 0,0912 & 0,0748 & 0,0523 & 0,0784 & 0,0576 & 2,5775 \\
\hline & İnşaat (6) & 0,0062 & 0,0096 & 0,0100 & 0,0137 & 0,0409 & 1,1967 & 0,0225 & 0,0080 & 0,0208 & 0,0226 & 1,3510 \\
\hline & Ticaret (7) & 0,0672 & 0,0817 & 0,1510 & 0,1433 & 0,0595 & 0,1305 & 1,2706 & 0,1131 & 0,0921 & 0,0440 & 2,1530 \\
\hline & Ulaștırma (8) & 0,0439 & 0,1079 & 0,1049 & 0,1108 & 0,0641 & 0,0832 & 0,1143 & 1,3008 & 0,0764 & 0,0403 & 2,0466 \\
\hline & Turizm (9) & 0,0021 & 0,0059 & 0,0059 & 0,0081 & 0,0051 & 0,0066 & 0,0167 & 0,0080 & 1,0794 & 0,0105 & 1,1483 \\
\hline & Hizmetler (10) & 0,0445 & 0,1132 & 0,1085 & 0,1475 & 0,1420 & 0,1491 & 0,2866 & 0,1234 & 0,1791 & 1,2050 & 2,4990 \\
\hline & Toplam & 1,7206 & 1,8455 & 2,4109 & 2,6477 & 2,7010 & 2,4707 & 2,1063 & 2,0027 & 2,0324 & 1,6007 & \\
\hline
\end{tabular}

Yukarıdaki Leontief ters matrisinde doğrudan ve dolaylı ileri bağlantı katsayısı (satır toplamı) ve doğrudan ve dolaylı geri bağlantı katsayısı (sütun toplamı) değerlerinin toplamı alındığında Türkiye'de "İmalat" sektörününün lokomotif sektör ya da kilit sektör olduğu görülmektedir. İleri ve geri bağlantı katsayıları toplamı en düşük diğer bir ifadeyle ekonomiyi harekete geçirme potansiyeli en düşük olan sektör ise "Turizm" sektörüdür. Kilit sektörün ya da sektörlerin belirlenmesinde tüm sektörlerin görünümü Şekil 2'de sunulmuștur.

Şekil 2: Türkiye Ekonomisinde Kilit (Lokomotif) Sektörün Belirlenmesi

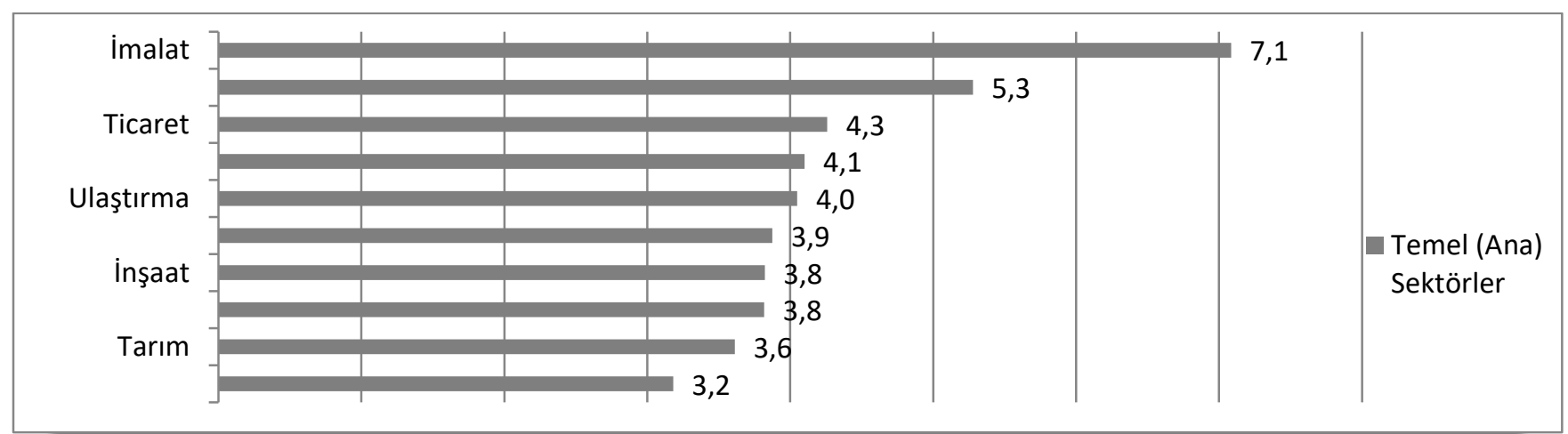

Şekil 2'ye göre ekonomiyi harekete geçirme potansiyeli açısından en yüksekten en düşüğe göre sıralama şöyledir: 1) İmalat $(7,0839), 2)$ Enerji $(5,2784), 3)$ Ticaret $(4,2592), 4)$ Hizmetler $(4,0996), 5)$ Ulaştırma $(4,0493), 6)$ Gıda $(3,8746), 7)$ İnşaat $(3,8217), 8)$ Madencilik (3,8181), 9) Tarım (3,6114), 10) Turizm $(3,1807)$. Ekonomide bir sektörün ileri ve geri bağlantı katsayılarını toplamını dikkate alarak kilit sektörü belirleyen bu analizde on sektörün ortalama değeri 4,31'dir. Buna göre Türkiye'de ortalama değerin üzerinde olan imalat sanayi ve enerji sektörleri kilit sektörlerdir. Diğer taraftan TÜí'in yayınladığı 2012 girdi-çıktı tablosunun en alt kısmında sektörel üretim içinde o sektörün ürünlerinden alınan vergileri, o sektörde çalışanlara yapılan ödemeleri, o sektörün yarattığı gayri safi katma değeri ve o sektörün yaptığı ithalatı gösteren veriler bulunmaktadır. Toplulaştırılarak diğer bir deyişle ana tablodaki satır ve sütun toplamları alınarak hesaplanan EK 1'den elde edilen nihai talep unsurlarının (ürün üzerindeki vergiler, çalışanlara yapılan ödemeler, gayrisafi katma değer, ithalat) her birinin sütun toplamlarından oluşan "üretim toplamı" değerine bölünerek elde edilen Tablo 4 aşağıda verilmiştir. 
Tablo 4: Nihai Talep Unsurlarının Toplam Üretim Değerlerine Oranı

\begin{tabular}{|c|c|c|c|c|c|c|c|c|c|c|}
\hline & Tarım & Madencilik & Gida & İmalat & Enerji & İnşaat & Ticaret & Ulaştırma & Turizm & Hizmetler \\
\hline Ürün Üzerindeki Vergiler & 0,0133 & 0,0409 & 0,0089 & 0,0375 & 0,0389 & 0,0202 & 0,0196 & 0,0647 & 0,0237 & 0,0140 \\
\hline Çalışanlara Yapılan Ödemeler & 0,0179 & 0,1613 & 0,0774 & 0,1017 & 0,0502 & 0,0955 & 0,1908 & 0,0802 & 0,1791 & 0,2924 \\
\hline Gayrisafi Katma Değer & 0,6404 & 0,5772 & 0,2909 & 0,2780 & 0,2502 & 0,3736 & 0,6022 & 0,4728 & 0,4910 & 0,6876 \\
\hline İthalat & 0,0785 & 2,3253 & 0,0637 & 0,4276 & 0,1179 & 0,0021 & 0,0000 & 0,0184 & 0,0208 & 0,0117 \\
\hline
\end{tabular}

Bir nihai talep unsurunun genel ekonomiyi nasıl etkilediğini bulabilmek için Tablo 4'deki satır şeklinde olan her bir nihai talep unsuru oranının transpozu (devriği) alınarak sütun şeklinde yazılır ve elde edilen $(10 \times 1)$ düzenindeki matris $(10 \times 10)$ düzenindeki Lontief ters matrisi $(\mathrm{I}-\mathrm{A})^{-1}$ ile çarpılır. Elde edilen yeni tablolardaki (Tablo 5, Tablo 6, Tablo 7, Tablo 8) sütun değerleri toplamı her bir sektörde o sektörün nihai talebindeki değişim sonucundaki etkiyi gösterecektir.

Temel sektörlerdeki bir birimlik üretim artışının diğer bir ifadeyle o sektöre olan nihai talepteki bir birimlik artışın çalışanlara yapılan ödemelere etkisi Tablo 5'te gösterilmiștir.

Tablo 5: Sektörlerdeki Büyümenin Çalışanlara Yapılan Ödemelere Etkisi

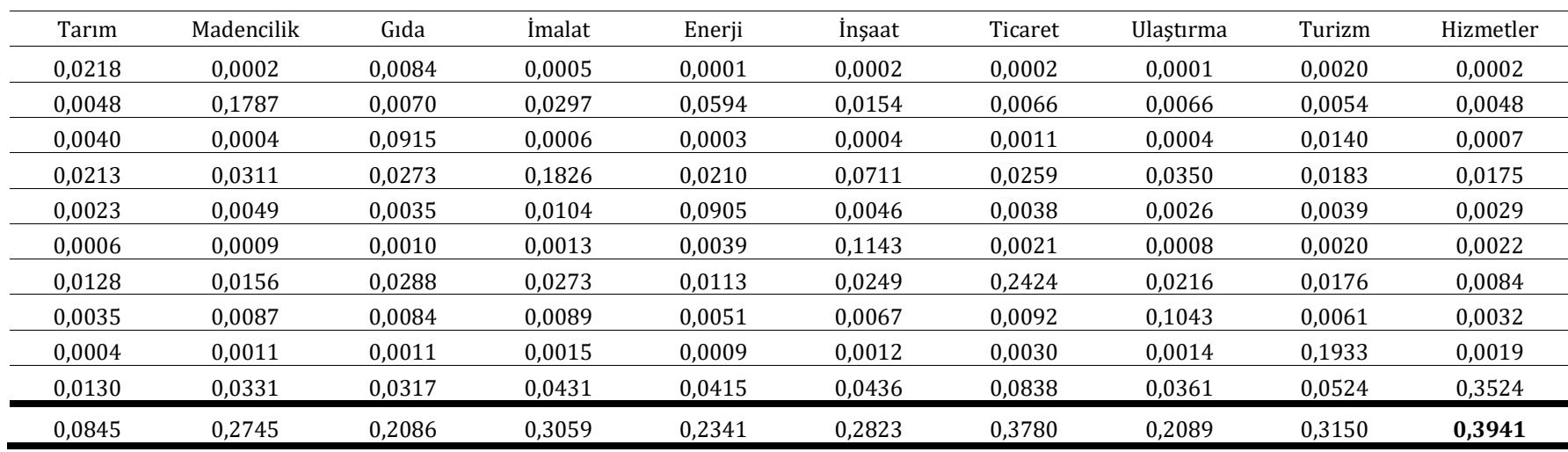

Tablo 5'te ekonominin on temel sektörü içerisinde herhangi bir sektörde üretim artışı ya da nihai talep artışı gerçekleştiğinde o sektörde çalışanlara yapılan ödeme oranları gösterilmektedir. Buna göre örneğin; "Tarım" sektöründe her 1 birimlik üretim artışında ya da tarım sektörü ürünlerine her 1 birimlik nihai talep artışında 0,0845 birim çalıșanlara ödeme artışı yapılmaktadır. Buna göre "Hizmetler" sektöründe 1 birimlik üretim artışı, söz konusu sektörde 0,3941 birim olarak çalışanlara ödeme ortaya çıkarmaktadır. Sektörlerdeki büyümenin ya da gelişmenin çalışanlara yapılan ödemelere etkisi Şekil 3'te gösterilmiştir.

Şekil 3: Sektörlerdeki Büyümenin Çalıșanlara Yapılan Ödemelere Etkisi

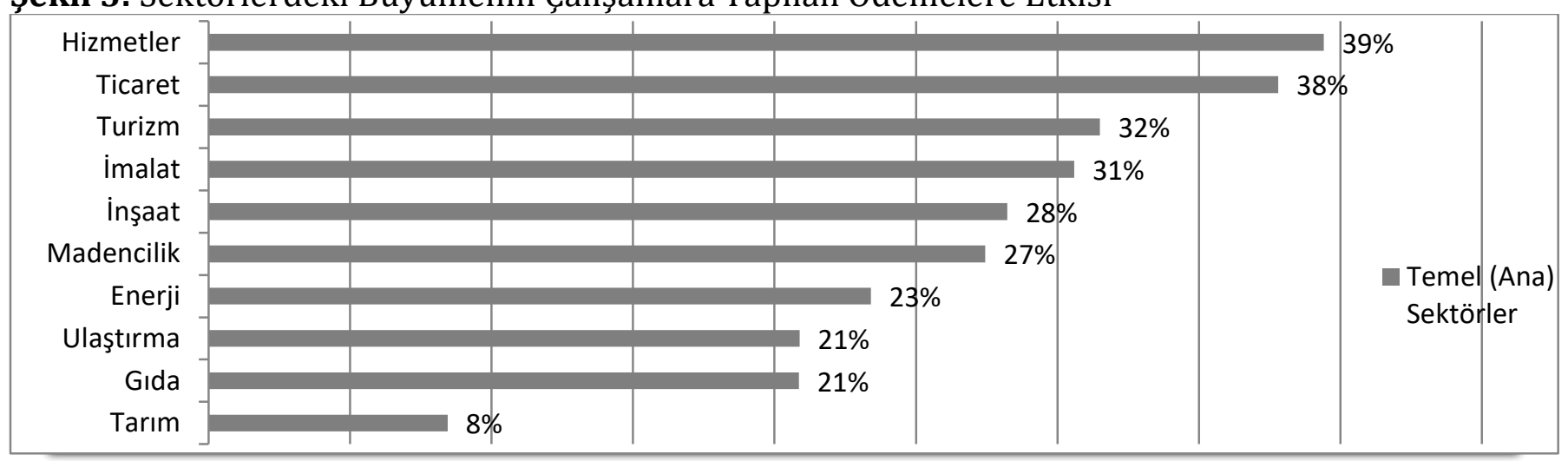


Şekil 3'e göre üretim artışı durumunda "Hizmetler" sektöründe çalışanlara üretimdeki veya o sektöre olan nihai talepteki artışın yaklaşık \% 39'u kadar bir oranla en yüksek düzeyde ödeme yapılmaktadır. $\mathrm{Bu}$ görünüm hizmetler sektöründe toplam giderler içerisinde personel giderlerinin büyük pay sahibi olması ve en alt sırada olan tarım sektöründe ise çalışanların çoğu zaman ücretsiz aile işçisi olmasıyla açıklanabilir.

Temel sektörlerdeki bir birimlik üretim artışının diğer bir ifadeyle o sektöre olan nihai talepteki bir birimlik artışın gayri safi katma değere etkisi Tablo 6'da gösterilmiştir.

Tablo 6: Sektörlerdeki Büyümenin Gayri Safi Katma Değere Etkisi

\begin{tabular}{ccccccccccc}
\hline Tarım & Madencilik & Glda & İmalat & Enerji & İşaat & Ticaret & Ulaştırma & Turizm & Hizmetler \\
\hline 0,7817 & 0,0077 & 0,2993 & 0,0190 & 0,0045 & 0,0086 & 0,0074 & 0,0049 & 0,0714 & 0,0062 \\
\hline 0,0170 & 0,6392 & 0,0250 & 0,1062 & 0,2125 & 0,0550 & 0,0237 & 0,0235 & 0,0193 & 0,0172 \\
\hline 0,0151 & 0,0014 & 0,3438 & 0,0023 & 0,0012 & 0,0015 & 0,0040 & 0,0014 & 0,0527 & 0,0025 \\
\hline 0,0581 & 0,0850 & 0,0747 & 0,4992 & 0,0573 & 0,1944 & 0,0708 & 0,0957 & 0,0500 & 0,0480 \\
\hline 0,0114 & 0,0243 & 0,0173 & 0,0518 & 0,4515 & 0,0228 & 0,0187 & 0,0131 & 0,0196 & 0,0144 \\
\hline 0,0023 & 0,0036 & 0,0037 & 0,0051 & 0,0153 & 0,4471 & 0,0084 & 0,0030 & 0,0078 & 0,0084 \\
\hline 0,0405 & 0,0492 & 0,0909 & 0,0863 & 0,0358 & 0,0786 & 0,7651 & 0,0681 & 0,0555 & 0,0265 \\
\hline 0,0208 & 0,0510 & 0,0496 & 0,0524 & 0,0303 & 0,0393 & 0,0540 & 0,6150 & 0,0361 & 0,0191 \\
\hline 0,0010 & 0,0029 & 0,0029 & 0,0040 & 0,0025 & 0,0032 & 0,0082 & 0,0039 & 0,5300 & 0,0052 \\
\hline 0,0306 & 0,0779 & 0,0746 & 0,1014 & 0,0976 & 0,1025 & 0,1970 & 0,0849 & 0,1232 & 0,8285 \\
\hline 0,9785 & 0,9422 & 0,9819 & 0,9276 & 0,9084 & 0,9531 & $\mathbf{1 , 1 5 7 4}$ & 0,9133 & 0,9656 & 0,9760 \\
\hline
\end{tabular}

Sütun değerlerinin toplamlarını ifade eden Tablo 6'nın en alt satırında temel sektörlerde her 1 birimlik üretim artışı sonucunda o sektörün katma değer olarak ekonomiye olan katkı oranı gösterilmiştir. Söz konusu orjinal tablo Şekil 4'te özetlenmeye çalışılmıştır.

Şekil 4: Sektörlerdeki Büyümenin Gayri Safi Katma Değere Etkisi

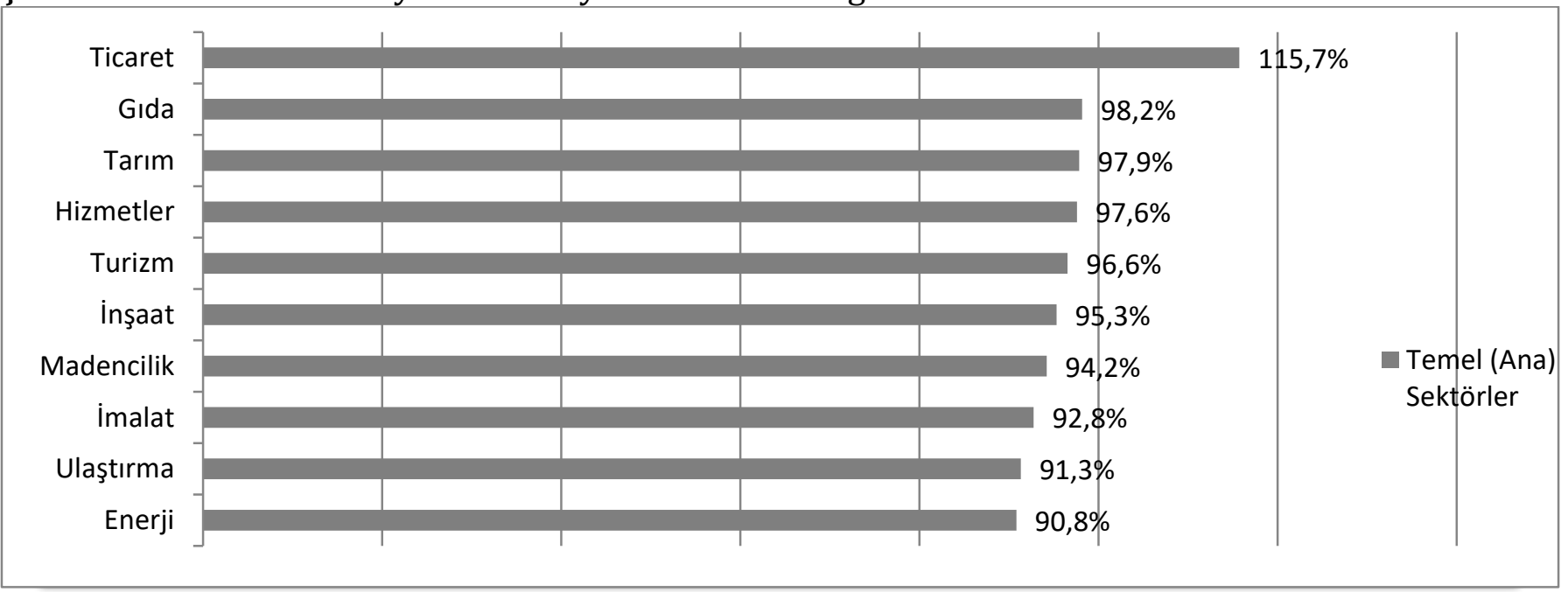

Şekil 4'e göre on sektör içerisinde sırasıyla "Ticaret", "Gıda" ve "Tarım" sektörleri gayri safi katma değeri en yüksek; "Enerji", "Ulaştırma" ve "İmalat" sektörleri de gayri safi katma değeri en düşük sektörlerdir. Buradaki katma değer hesaplamasının mamüle yapılan net katkı olarak değil de daha ziyade mamulün ya da işleme konu olan ekonomik değerin alış- 
satıș fiyatı arasındaki farkı ifade ettiğine dikkat edilmelidir. Bir başka ifadeyle ekonominin değer zinciri içerisinde özellikle "Ticaret" sektöründe alış ve satış fiyatları arasında yüksek bir marj olduğu ileri sürülebilir.
Temel sektörlerdeki bir birimlik üretim artışının başka bir deyişle o sektöre olan nihai talepteki bir birimlik artışın ürün üzerindeki vergilere etkisi Tablo 7'de gösterilmiștir.

Tablo 7: Sektörlerdeki Büyümenin Ürün Üzerindeki Vergilere Etkisi

\begin{tabular}{|c|c|c|c|c|c|c|c|c|c|}
\hline Tarım & Madencilik & Gida & İmalat & Enerji & İnşaat & Ticaret & Ulaştırma & Turizm & Hizmetler \\
\hline 0,0163 & 0,0002 & 0,0062 & 0,0004 & 0,0001 & 0,0002 & 0,0002 & 0,0001 & 0,0015 & 0,0001 \\
\hline 0,0012 & 0,0453 & 0,0018 & 0,0075 & 0,0150 & 0,0039 & 0,0017 & 0,0017 & 0,0014 & 0,0012 \\
\hline 0,0005 & 0,0000 & 0,0105 & 0,0001 & 0,0000 & 0,0000 & 0,0001 & 0,0000 & 0,0016 & 0,0001 \\
\hline 0,0078 & 0,0115 & 0,0101 & 0,0674 & 0,0077 & 0,0263 & 0,0096 & 0,0129 & 0,0068 & 0,0065 \\
\hline 0,0001 & 0,0002 & 0,0002 & 0,0003 & 0,0008 & 0,0242 & 0,0005 & 0,0002 & 0,0004 & 0,0005 \\
\hline 0,0013 & 0,0016 & 0,0030 & 0,0028 & 0,0012 & 0,0026 & 0,0249 & 0,0022 & 0,0018 & 0,0009 \\
\hline 0,0028 & 0,0070 & 0,0068 & 0,0072 & 0,0041 & 0,0054 & 0,0074 & 0,0842 & 0,0049 & 0,0026 \\
\hline 0,0000 & 0,0001 & 0,0001 & 0,0002 & 0,0001 & 0,0002 & 0,0004 & 0,0002 & 0,0255 & 0,0002 \\
\hline 0,0006 & 0,0016 & 0,0015 & 0,0021 & 0,0020 & 0,0021 & 0,0040 & 0,0017 & 0,0025 & 0,0169 \\
\hline 0,0325 & 0,0712 & 0,0429 & 0,0960 & 0,1014 & 0,0683 & 0,0516 & 0,1052 & 0,0495 & 0,0312 \\
\hline
\end{tabular}

Tablo 7'ye göre ulaștırma sektöründeki üretim artışının diğer bir ifadeyle söz konusu sektöre olan nihai talepteki artışın yaklaşık \%10'u vergi olarak devlete ödenmektedir. Vergi etkisi açısından sektörler arası karşılaştırma Şekil 5'te sunulmuştur.

Şekil 5: Sektörlerdeki Büyümenin Ürün Üzerindeki Vergilere Etkisi

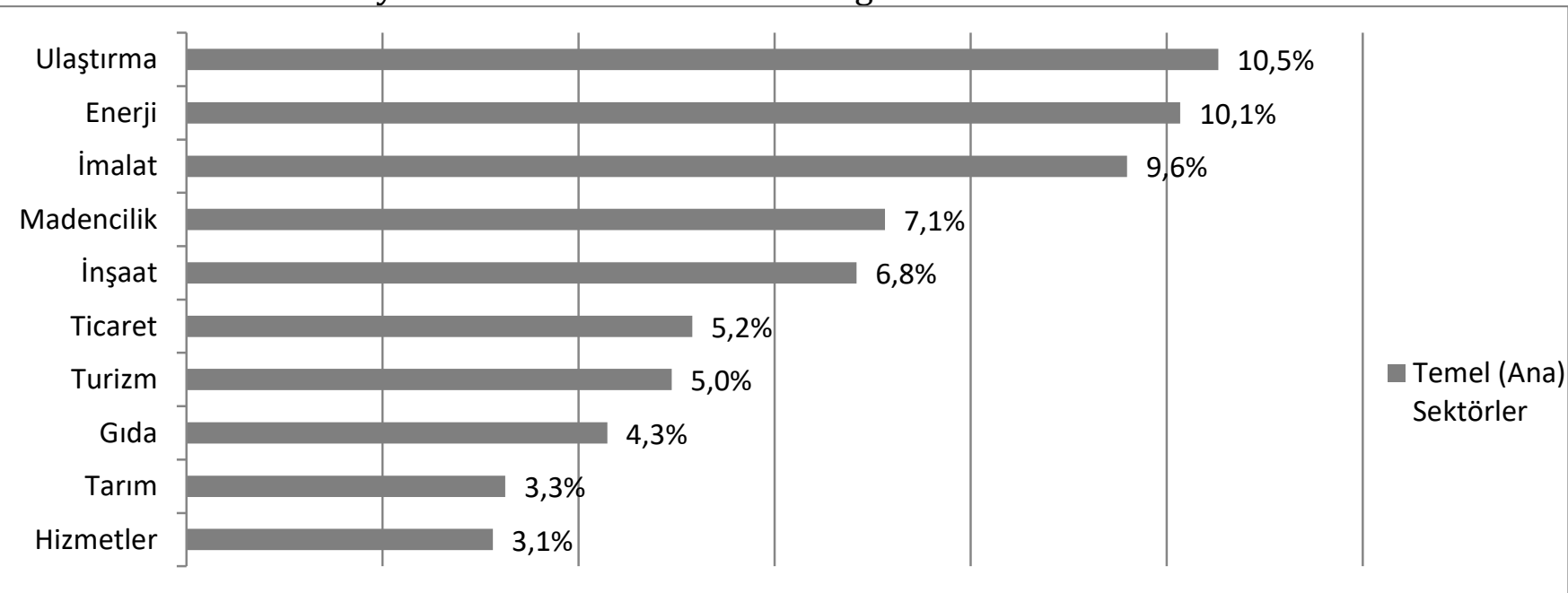

Şekil 5'e göre temel sektörler içerisinde sırasıyla "Ulaştırma", "Enerji" ve "İmalat" sektörlerinin vergi yaratma kapasitesinin yüksek olduğu görülmektedir. Yine "Hizmetler", "Tarım" ve "Gıda" sektörlerinin ise vergi oluşturma yeteneğinin en az olduğu görülmektedir. Şekil 5 "(31) kara taşımacılığ ve boru hattı taşımacıllğı hizmetleri”, "(32) su yolu taşımacılığı hizmetleri”, "(33) hava yolu taşımacıllğı hizmetler" ve "(34) depolama ve destek hizmetleri, taşımacılık için" (Bkz. EK 2) alt sektörlerinin toplamından oluşan ulaştırma sektöründe ya vergi oranları çok yüksek ya da kayıtdışlık diğer ana sektörlere göre daha azdır. Diğer bir deyișle Türkiye'de üretim değeri açısından ikinci büyük ana sektör olan 


\section{E. YENISU}

hizmetler sektöründe ya kamunun vergi talebi çok düşük ya da bu sektörde kayıtdışılık diğer ana sektörlere nazaran önemli ölçüde yüksektir.
Temel sektörlerdeki bir birimlik üretim artışının başka bir ifadeyle o sektöre olan nihai talepteki bir birimlik artışın ithalata etkisi Tablo 8'de gösterilmiştir.

Tablo 8: Sektörlerdeki Büyümenin İthalata Etkisi

\begin{tabular}{ccccccccccc}
\hline Tarım & Madencilik & Glda & İmalat & Enerji & İşaat & Ticaret & Ulaştırma & Turizm & Hizmetler \\
\hline 0,0958 & 0,0009 & 0,0367 & 0,0023 & 0,0005 & 0,0011 & 0,0009 & 0,0006 & 0,0088 & 0,0008 \\
\hline 0,0686 & 2,5750 & 0,1008 & 0,4279 & 0,8559 & 0,2215 & 0,0954 & 0,0945 & 0,0779 & 0,0694 \\
\hline 0,0033 & 0,0003 & 0,0753 & 0,0005 & 0,0003 & 0,0003 & 0,0009 & 0,0003 & 0,0115 & 0,0005 \\
\hline 0,0894 & 0,1307 & 0,1149 & 0,7679 & 0,0881 & 0,2991 & 0,1089 & 0,1472 & 0,0769 & 0,0738 \\
\hline 0,0054 & 0,0115 & 0,0082 & 0,0244 & 0,2128 & 0,0108 & 0,0088 & 0,0062 & 0,0092 & 0,0068 \\
\hline 0,0000 & 0,0000 & 0,0000 & 0,0000 & 0,0001 & 0,0025 & 0,0000 & 0,0000 & 0,0000 & 0,0000 \\
\hline 0,0000 & 0,0000 & 0,0000 & 0,0000 & 0,0000 & 0,0000 & 0,0000 & 0,0000 & 0,0000 & 0,0000 \\
\hline 0,0008 & 0,0020 & 0,0019 & 0,0020 & 0,0012 & 0,0015 & 0,0021 & 0,0239 & 0,0014 & 0,0007 \\
\hline 0,0000 & 0,0001 & 0,0001 & 0,0002 & 0,0001 & 0,0001 & 0,0003 & 0,0002 & 0,0225 & 0,0002 \\
\hline 0,0005 & 0,0013 & 0,0013 & 0,0017 & 0,0017 & 0,0018 & 0,0034 & 0,0014 & 0,0021 & 0,0141 \\
\hline 0,2639 & $\mathbf{2 , 7 2 1 9}$ & 0,3392 & 1,2270 & 1,1607 & 0,5386 & 0,2207 & 0,2743 & 0,2104 & 0,1664 \\
\hline
\end{tabular}

Șekil 6 hangi sektörlerin ithal bağımlılığının yüksek ya da düşük olduğunu göstermektedir. Buna göre "Madencilik" sektöründen 1 birimlik üretim ya da nihai talep artıșı yaklașık 2,7 birimlik ithalatı uyarmaktadır. Sektörlerdeki gelişmenin ithalata olan etkisi Şekil 6'da sıralanmıştır.

Şekil 6: Sektörlerdeki Büyümenin İthalata Etkisi

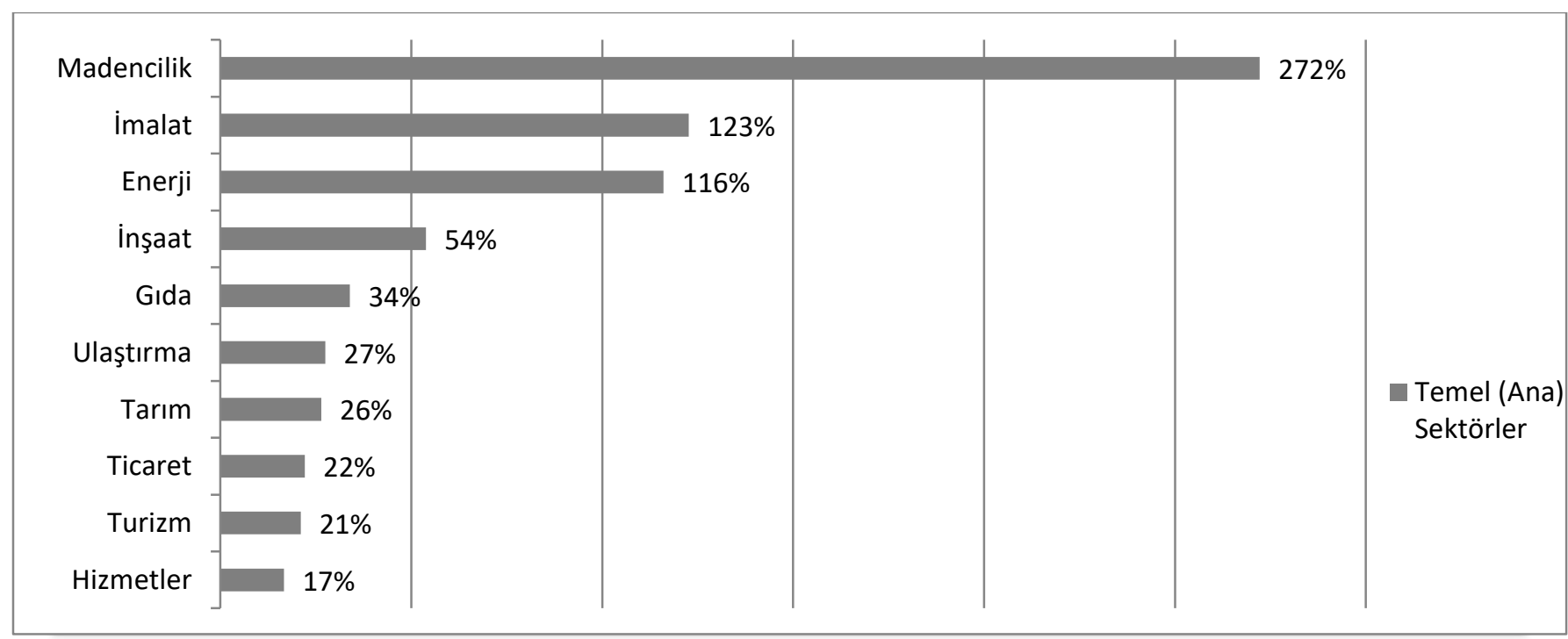

Şekil 6'ya göre "Madencilik", "İmalat" ve "Enerji" sektörleri yoğun ithal girdi kullanan önemli sektörlerdir. Diğer yedi sektörün ise ithal girdi bağımlılığının düşük olduğu söylenebilir. Burada "İnşaat" sektörünün ilk üç sektör bir tarafa konulursa diğer sektör ortalamalarının yaklaşık iki katı büyüklükte bir ithalatı uyarması da dikkat çekicidir. Diğer taraftan içerisinde ham petrol, doğalgaz ve taşkömürü ithalini barındıran "Madencilik" sektörüyle "Enerji" sektöründe ithal bağımlılığının yüksek çıkma sebebi Türkiye'nin enerjide dışa bağımlı bir ülke olmasıdır. Kısacası bu iki ana sektörde ithal girdi kullanım katsayısının yüksek çıkması beklenen bir sonuçtur. Son olarak bu sonuçlara 
göre Türkiye'de üretim açısından en büyük ana sektör olan "İmalat" sektörünün ithal girdi kullanım oranının yüksek çıkması dikkate değerdir.

\section{SONUÇ VE ÖNERILER}

Türkiye ekonomisinin yapısal görünümüne bakıldığında ileri dünya ülkelerinden oldukça geride olduğumuz söylenebilir. Türkiye gelişmiş ülkeler ile az gelişmiş ülkeler arasında yer alan bir geçiş ülkesidir. Geçiş ülkelerinin ekonomik sorunları muhakkak ki uzun vadeli, politika üstü ve kendine has çözüm yöntemlerini gerektirmektedir. Bu çalışmada Türkiye ekonomisinin yapısal özelliklerini açıklamada kullanılabilecek kapsamlı bir analiz yöntemi olan girdi-çıktı analizi uygulanmıștır. Șüphesiz araștırmacılar söz konusu analizden kök alan daha detaylı yöntemlerle uluslararası, ulusal, bölgesel veya sektörel ekonomiye dair önemli bilgiler edinebilirler.

Ekonominin lokomotifi olan temel sektörleri belirlemeyi amaçlayan bu çalışmaya göre Türkiye'de sırasıyla "İmalat Sanayi" ve "Enerji" sektörleri kilit sektörlerdir. Temel sektörler itibariyle üretimdeki artışın çalışanlara yapılan ödemelere etkisi açısındansa "Hizmetler" ve "Ticaret" sektörleri önde gelmektedir. Diğer taraftan gayri safi katma değer olușturma bakımından temel sektörlerin benzer özellikler taşıldı̆̆ tespit edilmiştir. Sektörlerdeki büyümenin vergi yaratabilme kapasitesi açısından ise "Ulaştırma", "Enerji" ve "İmalat Sanayi" sektörlerinin ilk üçte olduğu görülmüștür. Son olarak, bu çalışmada "Madencilik", "Enerji" ve "Imalat Sanayi" sektörlerinde yüksek bir ithal girdi kullanım oranı olduğu bulgulanmıştır.

Çalışmada elde edilen temel sonuç TÜIK'in 2002 yılı girdi-çıtı tablosunu analiz eden Atan (2011) ve Özdemir ve Mercan (2012)'in sonuçlarıyla uyuşmaktadır. Bununla birlikte çalışmamızda elde edilen temel bulgular "World Input-Output Database" 1995-2011 girdi-çıktı tablolarını analiz eden Uğurlu ve Tuncer (2017)'in sonuçlarıyla da aynı yöndedir. Diğer taraftan ilgili yazında bu çalışmanın sonuçlarıyla çelişen herhangi bir yayın saptanamamıştır.

Kısacası bu çalışmada elde edilen bulgulardan yola çıkılarak imalat sanayi sektörüne yapılan doğrudan veya dolaylı teşviklerin yeniden değerlendirilmesi ve enerji politikalarında daha aktif olunarak enerji kaynaklarının çeșitlendirilmesi önerilmektedir. Bu önerileri gerçekleștirmeye yönelik adımlar atılması ekonominin yapısal iyiliğine katkıda bulunabilir.

\section{KAYNAKÇA}

Atan, S. (2011). Türkiye'deki Sektörel Bağlantı Yapısının Girdi-Çııtı Yaklaşımı İle İncelenmesi: Yurtiçi Üretim ve İthal Ara Girdi Ayrıștırması. Ekonomik Yaklaşım, 22(80), 59-78.

Atan, S. ve Arslanturk, Y. (2012). Tourism and Economic Growth Nexus: An Input Output Analysis in Turkey. Procedia-Social and Behavioral Sciences, 62(24), 952-956.

Ayaş, N. (2016). Türkiye Ekonomisinde Hizmetler Sektörünün Ekonomik Etkilerinin Girdi Çıktı Modeli ile Analizi (1995-2011). Afyon Kocatepe Üniversitesi İktisadi ve İdari Bilimler Fakültesi Dergisi, 18(2), 89-102.

Bekhet, H.A., Abdullah, A., 2010). Energy Use in Agriculture Sector: Input-Output Analysis,
International Business Research, 3(3), 111121.

Berument, H. ve Taşçı, H. (2002). Inflationary Effect of Crude Oil Prices in Turkey, Physica, 316, 568-580.

Bon, R., Birgönül, T. ve Özdoğan, İ. (1999). An Input-Output Analysis of the Turkish Construction Sector, 1973-1990: A Note. Construction Management \& Economics, 17(5), 543-551.

Canl, B. ve Kaya, A. A. (2012). Türk Turizm Sektorünün Ekonomik Etkilerinin Girdi Çıtı Yaklaşımıyla Ölçülmesi. Anadolu Üniversitesi Sosyal Bilimler Dergisi, 12(1), 1-12. 
Chase, R. A., Bourque, P. ve Conway, R. (1993). The 1987 Washington State Input-Output Study. Graduate School of Business Administration University of Washington, Office of Financial Management Forecasting Division.

Çalışkan E. T. ve Aydoğuş, O. (2011). Türkiye Ekonomisinde Endüstriyel Büyümenin Kaynakları: Girdi-Çıktı Modeli ile Ampirik Bir Analiz (1985-2002). Ege Akademik Bakış, 11(4), 499-510.

Çondur, F. ve Evlimoğlu, U. (2007). Türkiye'de Madencilik Sektörünün Girdi-Çılktı Analizi Yöntemiyle İncelenmesi. Manas Üniversitesi Sosyal Bilimler Dergisi, 9(18), 25-41.

Ersungur, Ş. M. ve Kızlltan, A. (2007). Türkiye Ekonomisinde İthalata Bağımlılığın Girdi-Çılktı Yöntemiyle Analizi. Atatürk Üniversitesi Sosyal Bilimler Enstitüsü Dergisi, 9(1), 267278.

Gül, Z. B. ve Çakaloğlu, M. (2017). İnşaat Sektörünün Dinamikleri: Türkiye İçin 20002014 Girdi-Çıktı Analizi. Akdeniz İktisadi ve İdari Bilimler Fakültesi Dergisi, (36), 130-155.

Gül, Z. B., Çağatay, S. ve Taşdoğan, C. (2014). Input-Output Analysis of Turkish Construction Industry by Using World Input-Output Database for 2002-2011 Period, 22nd InputOutput Society Conference, 17-19 July, Portugal.

Gündeş, S. (2011). Exploring The Dynamics of the Turkish Construction Industry Using Input-Output Analysis. Construction Management and Economics, 29(1), 59-68.

Karkacier, O. (2018). Antalya İli Tarıma Dayalı Sanayinin Yapısal Analizi. Türk Tarım-Gıda Bilgi ve Teknololji Dergisi, 6(6), 740-748.

Karkacier, O. ve Bölük, G. (2017). The Structural Analysis of Agriculture, Food And Energy Sectors in Turkey: An Input-Output Model. Al-Farabi Uluslararası Sosyal Bilimler Dergisi, 1(2), 289-305.
Kofoworola, O. F. ve Gheewala, S. (2008). An Input-Output Analysis of Thailand's Construction Sector. Construction Management and Economics, 26(11), 12271240.

Leontief, W. (1966). Input-Output Economics. New York: Oxford University Press.

Maden, S. I. ve Ertürk, M. (2019). Türk Turizm Sektörünün Türkiye Ekonomisine Olan Etkilerinin Girdi-Çıktı Analiziyle İncelenmesi. Doğuş Üniversitesi Dergisi, 20(2), 69-87.

Özdemir, A. ve Mercan, M. (2012). Türkiye'de Enerji Sektöründe Yapısal Bağınlaşma: GirdiÇıktı Analizi. Business And Economics Research Journal, 3(2), 111-133.

Özdil, T. (1993). Türkiye Ekonomisindeki Yapısal Degişime Girdi-Çıktı Analiziyle Bir Yaklaşım. Eskişehir Anadolu Üniversitesi İktisadi ve İdari Bilimler Fakültesi Dergisi, 11, 109-128.

Özkan, B., Akçaöz, H. ve Fert, C. (2004). Energy Input-Output Analysis in Turkish Agriculture. Renewable Energy, 29, 39-51.

Surugiu, C., Frent, C. ve Surugiu, M. (2009). Tourism and It's Impact Upon The Romanian Economy: An Input-Output Approach. Analele Stiintifice Ale Universiatii, 56(11), 355-376.

Tok, E. Ö. ve Sevinç, O. (2019). Üretimin İthal Girdi Yoğunluğu: Girdi-Çılktı Analizi. Türkiye Cumhuriyet Merkez Bankası-Ekonomi Notları, 6, 1-14.

TÜİK (2012) Girdi-Çılktı Tablosu, http://www.tuik.gov.tr, Erişim: 04.04.2020

Uğurlu, A. A. ve Tuncer, İ. (2017). Türkiye'de Sanayi ve Hizmet Sektörlerinin Büyüme ve İstihdama Katkıları: Girdi-Çıktı Analizi. Dokuz Eylül Üniversitesi İktisadi ve İdari Bilimler Fakültesi Dergisi, 32(1), 131-165.

Yılancl, V . (2008). Türkiye Ekonomisi İçin Kilit Sektörün Belirlenmesi Girdi Çıktı Analizi Yaklaşımı. İstanbul Üniversitesi İktisat Fakültesi Mecmuası , 58(2) , 75-86. 
EK 1: Toplulaştırılmış Temel Sektörler Girdi-Çılktı Tablosu (2012-TÜİK)

(Bin TL)

\begin{tabular}{|c|c|c|c|c|c|c|c|c|c|c|c|}
\hline & Tarım & Madencilik & Gida & İmalat & Enerji & İnşaat & Ticaret & Ulaştırma & Turizm & Hizmetler & Ara Tüketim Toplamı \\
\hline Tarım & 29.438 .082 & 133.291 & 56.673 .948 & 8.442 .260 & 8.946 & 114.145 & 194.336 & 15.671 & 3.623 .424 & 1.680 .161 & 100.324 .264 \\
\hline Madencilik & 452.063 & 1.946 .322 & 839.462 & 54.419 .833 & 28.243 .154 & 4.902 .443 & 983.177 & 419.136 & 147.477 & 2.382 .401 & 94.735 .469 \\
\hline Gida & 6.367 .557 & 37.176 & 23.837 .174 & 1.096 .217 & 64.879 & 112.565 & 1.683 .537 & 183.010 & 17.505 .499 & 2.919 .315 & 53.806.928 \\
\hline İmalat & 14.684 .866 & 4.353 .603 & 11.427 .861 & 294.228 .440 & 3.220 .508 & 92.053 .729 & 22.912 .926 & 36.382 .615 & 5.129 .055 & 47.132 .219 & 531.525 .823 \\
\hline Enerji & 1.451 .502 & 985.592 & 2.005 .057 & 43.418 .616 & 66.634 .066 & 578.017 & 4.627.493 & 787.949 & 2.921 .675 & 11.967 .712 & 135.377 .677 \\
\hline İnşaat & 364.064 & 93.241 & 350.386 & 1.506 .928 & 2.587 .794 & 47.242 .346 & 2.851 .662 & 416.284 & 1.347 .468 & 9.983 .344 & 66.743.517 \\
\hline Ticaret & 5.064 .029 & 1.181 .494 & 12.378 .844 & 39.503 .760 & 1.326 .241 & 13.906 .932 & 54.736 .934 & 13.840 .648 & 4.528 .684 & 11.972 .999 & 158.440 .566 \\
\hline Ulaștırma & 2.653 .824 & 1.959 .997 & 7.683 .842 & 25.541 .267 & 1.225 .639 & 6.018 .683 & 16.259 .572 & 56.493 .970 & 3.835 .233 & 11.594 .623 & 133.266 .650 \\
\hline Turizm & 23.651 & 81.604 & 295.037 & 1.648 .406 & 128.588 & 399.965 & 2.788 .391 & 912.819 & 8.840 .599 & 5.093 .323 & 20.212 .384 \\
\hline Hizmetler & 1.400 .750 & 1.731 .005 & 5.838 .182 & 30.341 .068 & 6.544 .020 & 15.210 .257 & 49.594 .133 & 13.327 .055 & 12.998 .505 & 106.895 .655 & 243.880 .631 \\
\hline Toplam Girdiler & 61.900 .389 & 12.503 .325 & 121.329 .793 & 500.146 .796 & 109.983.837 & 180.539 .082 & 156.632 .159 & 122.779 .156 & 60.877 .620 & 211.621 .752 & 1.538.313.908 \\
\hline Ürün Üzerindeki Vergi. & 2.383 .189 & 1.338 .302 & 1.541 .553 & 27.422 .297 & 6.021 .497 & 6.028 .481 & 5.656 .661 & 17.182 .604 & 2.968 .590 & 9.958 .097 & 80.501 .271 \\
\hline Çalıșanlara Yapılan Öd. & 3.194 .349 & 5.281 .814 & 13.409 .074 & 74.283 .269 & 7.761 .753 & 28.437.936 & 55.062 .371 & 21.294 .925 & 22.467 .467 & 207.384.812 & 438.577 .769 \\
\hline Gayrisafi Katma Değer & 114.461 .092 & 18.896 .983 & 50.408 .452 & 203.092.952 & 38.715 .447 & 111.271 .698 & 173.821 .461 & 125.523 .236 & 61.593 .785 & 487.627 .661 & 1.385.412.768 \\
\hline İthalat & 14.033 .607 & 76.127 .459 & 11.039 .586 & 312.432 .649 & 18.248 .007 & 617.097 & 0 & 4.885.201 & 2.614 .216 & 8.327 .143 & 448.324.963 \\
\hline Üretim Toplam & 178.744 .670 & 32.738 .610 & 173.279.798 & 730.662 .044 & 154.720 .781 & 297.839.261 & 288.644.429 & 265.484.996 & 125.439 .994 & 709.207.511 & 2.956.762.095 \\
\hline
\end{tabular}

EK 2: TÜİK 2012 Girdi-Çıktı Tablosu Sektör Tanımlamaları

\begin{tabular}{|c|c|c|}
\hline Sektör No & Ürün Kod (CPA 2008) & Sektör Adı (Tanım) (CPA 2008) \\
\hline 1 & A01 & $\begin{array}{l}\text { Tarım ve avcılık ürünleri ve ilgili hizmetler } \\
\text { Products of agriculture, hunting and related services }\end{array}$ \\
\hline 2 & A02 & $\begin{array}{l}\text { Orman ürünleri ve ilgili hizmetler } \\
\text { Products of forestry, logging and related services }\end{array}$ \\
\hline 3 & A03 & $\begin{array}{l}\text { Balık ve diğer balıkçılık ürünleri; su ürünleri; balıkçılık için destekleyici } \\
\text { hizmetler } \\
\text { Fish and other fishing products; aquaculture products; support services to } \\
\text { fishing }\end{array}$ \\
\hline 4 & B & $\begin{array}{l}\text { Madencilik ve Taşocakçılığı } \\
\text { Mining and quarrying }\end{array}$ \\
\hline 5 & C10-C12 & $\begin{array}{l}\text { Gıda, içecekler ve tütün ürünleri } \\
\text { Food, beverages and tobacco products }\end{array}$ \\
\hline 6 & C13-C15 & $\begin{array}{l}\text { Tekstil, giyim eşyası, deri ve ilgili ürünler } \\
\text { Textiles, wearing apparel, leather and related products }\end{array}$ \\
\hline 7 & C16 & $\begin{array}{l}\text { Kereste, ağaç ürünleri ve mantar ürünleri (mobilya hariç); hasır ve örme } \\
\text { malzemesinden (saz, saman vb.) ürünler } \\
\text { Wood and of products of wood and cork, except furniture; articles of straw } \\
\text { and plaiting materials }\end{array}$ \\
\hline 8 & C17 & $\begin{array}{l}\text { Kağıt ve kağıt ürünleri } \\
\text { Paper and paper products }\end{array}$ \\
\hline 9 & C18 & $\begin{array}{l}\text { Basım ve kayıt hizmetleri } \\
\text { Printing and recording services }\end{array}$ \\
\hline 10 & C19 & $\begin{array}{l}\text { Kok ve rafine petrol ürünleri } \\
\text { Coke and refined petroleum products }\end{array}$ \\
\hline 11 & C20 & $\begin{array}{l}\text { Kimyasallar ve kimyasal ürünler } \\
\text { Chemicals and chemical products }\end{array}$ \\
\hline 12 & C21 & $\begin{array}{l}\text { Temel eczacılık ürünleri ve müstahzarları } \\
\text { Basic pharmaceutical products and pharmaceutical preparations }\end{array}$ \\
\hline 13 & C22 & $\begin{array}{l}\text { Kauçuk ve plastik ürünler } \\
\text { Rubber and plastic products }\end{array}$ \\
\hline
\end{tabular}




\section{E. YENISU}

EK 2: TÜİK 2012 Girdi-Çıktı Tablosu Sektör Tanımlamaları (Devamı)

\begin{tabular}{|c|c|c|}
\hline Sektör No & Ürün Kod (CPA 2008) & Sektör Adı (Tanım) (CPA 2008) \\
\hline 14 & $\mathrm{C} 23$ & $\begin{array}{l}\text { Diğer metalik olmayan mineral ürünleri } \\
\text { Other non-metallic mineral products }\end{array}$ \\
\hline 15 & $\mathrm{C} 24$ & $\begin{array}{l}\text { Ana metaller } \\
\text { Basic metals }\end{array}$ \\
\hline 16 & C25 & $\begin{array}{l}\text { Fabrikasyon metal ürünler, makine ve ekipmanlar hariç } \\
\text { Fabricated metal products, except machinery and equipment }\end{array}$ \\
\hline 17 & C26 & $\begin{array}{l}\text { Bilgisayarlar ile elektronik ve optik ürünler } \\
\text { Computer, electronic and optical products }\end{array}$ \\
\hline 18 & $\mathrm{C} 27$ & $\begin{array}{l}\text { Elektrikli teçhizat } \\
\text { Electrical equipment }\end{array}$ \\
\hline 19 & $\mathrm{C} 28$ & $\begin{array}{l}\text { Başka yerde sınıflandırılmamış makine ve ekipmanlar } \\
\text { Machinery and equipment n.e.c. }\end{array}$ \\
\hline 20 & $\mathrm{C} 29$ & $\begin{array}{l}\text { Motorlu kara taşıtları, treyler (römork) ve yarı treyler (yarı römork) } \\
\text { Motor vehicles, trailers and semi-trailers }\end{array}$ \\
\hline 21 & C30 & $\begin{array}{l}\text { Diğer ulaşım araçları } \\
\text { Other transport equipment }\end{array}$ \\
\hline 22 & C31_C32 & $\begin{array}{l}\text { Mobilya ve diğer mamul eşyalar } \\
\text { Furniture and other manufactured goods }\end{array}$ \\
\hline 23 & C33 & $\begin{array}{l}\text { Makine ve ekipmanların kurulumu ve onarımı } \\
\text { Repair and installation services of machinery and equipment }\end{array}$ \\
\hline 24 & D35 & $\begin{array}{l}\text { Elektrik, gaz, buhar ve iklimlendirme } \\
\text { Electricity, gas, steam and air conditioning }\end{array}$ \\
\hline 25 & E36 & $\begin{array}{l}\text { Doğal su; suyun arıtılması ve temini hizmetleri } \\
\text { Natural water; water treatment and supply services }\end{array}$ \\
\hline 26 & E37-E39 & $\begin{array}{l}\text { Kanalizasyon hizmetleri, kanalizasyon çamuru; atığın toplanması, } \\
\text { işlenmesi ve bertarafı; maddelerin geri kazanımı; iyileştirme hizmetleri } \\
\text { ve diğer atık yönetimi hizmetleri } \\
\text { Sewerage services; sewage sludge; waste collection, treatment and disposal } \\
\text { services; materials recovery services; remediation services and other wa... }\end{array}$ \\
\hline 27 & $\mathbf{F}$ & $\begin{array}{l}\text { İnşaatlar ve inşaat işleri } \\
\text { Constructions and construction works }\end{array}$ \\
\hline 28 & G45 & $\begin{array}{l}\text { Toptan ve perakende ticaret ile motorlu kara taşıtlarının ve } \\
\text { motosikletlerin onarım hizmetleri } \\
\text { Wholesale and retail trade and repair services of motor vehicles and } \\
\text { motorcycles }\end{array}$ \\
\hline 29 & G46 & $\begin{array}{l}\text { Toptan ticaret, motorlu kara taşıtları ve motosikletler hariç } \\
\text { Wholesale trade services, except of motor vehicles and motorcycles }\end{array}$ \\
\hline 30 & G47 & $\begin{array}{l}\text { Perakende ticaret (motorlu kara taşıtları ve motosikletler hariç) } \\
\text { Retail trade services, except of motor vehicles and motorcycles }\end{array}$ \\
\hline 31 & H49 & $\begin{array}{l}\text { Kara taşımacılığı ve boru hattı taşımacılığı hizmetleri } \\
\text { Land transport services and transport services via pipelines }\end{array}$ \\
\hline 32 & H50 & $\begin{array}{l}\text { Su yolu taşımacılı̆̆ hizmetleri } \\
\text { Water transport services }\end{array}$ \\
\hline 33 & H51 & $\begin{array}{l}\text { Hava yolu taşımacılığı hizmetleri } \\
\text { Air transport services }\end{array}$ \\
\hline 34 & H52 & $\begin{array}{l}\text { Depolama ve destek hizmetleri, taşımacılık için } \\
\text { Warehousing and support services for transportation }\end{array}$ \\
\hline 35 & H53 & $\begin{array}{l}\text { Posta ve kurye hizmetleri } \\
\text { Postal and courier services }\end{array}$ \\
\hline 36 & I & $\begin{array}{l}\text { Konaklama ve yiyecek hizmetleri } \\
\text { Accommodation and food services }\end{array}$ \\
\hline 37 & J58 & $\begin{array}{l}\text { Yayıncllık hizmetleri } \\
\text { Publishing services }\end{array}$ \\
\hline
\end{tabular}


EK 2: TÜİK 2012 Girdi-Çıktı Tablosu Sektör Tanımlamaları (Devamı)

\begin{tabular}{|c|c|c|}
\hline Sektör No & Ürün Kod (CPA 2008) & Sektör Adı (Tanım) (CPA 2008) \\
\hline 38 & J59_J60 & $\begin{array}{l}\text { Sinema filmi, video ve televizyon programı yapımcılık hizmetleri, ses } \\
\text { kaydı ve müzik yayımlama; programcılık ve yayıncılık hizmetleri } \\
\text { Motion picture, video and television programme production services, sound } \\
\text { recording and music publishing; programming and broadcasting services }\end{array}$ \\
\hline 39 & $\mathrm{~J} 61$ & $\begin{array}{l}\text { Telekomünikasyon hizmetleri } \\
\text { Telecommunications services }\end{array}$ \\
\hline 40 & J62_J63 & $\begin{array}{l}\text { Bilgisayar programlama, danışmanlık ve ilgili hizmetler; bilgi hizmetleri } \\
\text { Computer programming, consultancy and related services; Information } \\
\text { services }\end{array}$ \\
\hline 41 & K64 & $\begin{array}{l}\text { Finansal hizmetler (sigorta ve bireysel emeklilik hariç) } \\
\text { Financial services, except insurance and pension funding }\end{array}$ \\
\hline 42 & K65 & $\begin{array}{l}\text { Sigorta, reasürans ve emeklilik fonları hizmetleri, zorunlu sosyal } \\
\text { güvenlik hariç } \\
\text { Insurance, reinsurance and pension funding services, except compulsory } \\
\text { social security }\end{array}$ \\
\hline 43 & K66 & $\begin{array}{l}\text { Finansal hizmetler ile sigorta hizmetlerine yardımcı hizmetler } \\
\text { Services auxiliary to financial services and insurance services }\end{array}$ \\
\hline 44 & L68B & $\begin{array}{l}\text { Gayrimenkul hizmetleri } \\
\text { Real estate services excluding imputed rents }\end{array}$ \\
\hline 45 & L68A & $\begin{array}{l}\text { Kendi konutunda ikamet edenler için izafi kira } \\
\text { Imputed rents of owner-occupied dwellings }\end{array}$ \\
\hline 46 & M69_M70 & $\begin{array}{l}\text { Hukuk ve muhasebe hizmetleri; idare merkezi hizmetleri; idari } \\
\text { danışmanlık hizmetleri } \\
\text { Legal and accounting services;Services of head offices; management } \\
\text { consulting services }\end{array}$ \\
\hline 47 & M71 & $\begin{array}{l}\text { Mimarlık ve mühendislik hizmetleri; teknik test ve analiz hizmetleri } \\
\text { Architectural and engineering services; technical testing and analysis services }\end{array}$ \\
\hline 48 & M72 & $\begin{array}{l}\text { Bilimsel araştırma ve geliştirme hizmetleri } \\
\text { Scientific research and development services }\end{array}$ \\
\hline 49 & M73 & $\begin{array}{l}\text { Reklamcılık ve pazar araştırması hizmetleri } \\
\text { Advertising and market research services }\end{array}$ \\
\hline 50 & M74_M75 & $\begin{array}{l}\text { Diğer mesleki, bilimsel ve teknik hizmetler; veterinerlik hizmetleri } \\
\text { Other professional, scientific and technical services and veterinary services }\end{array}$ \\
\hline 51 & N77 & $\begin{array}{l}\text { Kiralama ve leasing hizmetleri } \\
\text { Rental and leasing services }\end{array}$ \\
\hline 52 & N78 & $\begin{array}{l}\text { İstihdam hizmetleri } \\
\text { Employment services } \\
\end{array}$ \\
\hline 53 & N79 & $\begin{array}{l}\text { Seyahat acentesi, tur operatörü, diğer rezervasyon hizmetleri ve ilgili } \\
\text { hizmetler } \\
\text { Travel agency, tour operator and other reservation services and related } \\
\text { services }\end{array}$ \\
\hline 54 & N80-N82 & $\begin{array}{l}\text { Güvenlik ve soruşturma hizmetleri; bina ve çevre düzenleme (peyzaj) } \\
\text { hizmetleri; büro yönetimi, büro destek ve diğer iş destek hizmetleri } \\
\text { Security and investigation services; services to buildings and landscape; office } \\
\text { administrative, office support and other business support services }\end{array}$ \\
\hline 55 & 084 & $\begin{array}{l}\text { Kamu yönetimi ve savunma hizmetleri; zorunlu sosyal güvenlik } \\
\text { hizmetleri } \\
\text { Public administration and defence services; compulsory social security } \\
\text { services }\end{array}$ \\
\hline
\end{tabular}




\section{E. YENISSU}

EK 2: TÜİK 2012 Girdi-Çıktı Tablosu Sektör Tanımlamaları (Devamı)

\begin{tabular}{|l|l|l|}
\hline Sektör No & Ürün Kod (CPA 2008) & Sektör Adı (Tanım) (CPA 2008) \\
\hline 56 & P85 & $\begin{array}{l}\text { Eğitim hizmetleri } \\
\text { Education services }\end{array}$ \\
\hline 57 & Q86 & $\begin{array}{l}\text { İnsan sağlı̆ı hizmetleri } \\
\text { Human health services }\end{array}$ \\
\hline 58 & Q87_Q88 & $\begin{array}{l}\text { Yatılı bakım hizmetleri; barınacak yer sağlanmaksızın verilen sosyal } \\
\text { hizmetler } \\
\text { Residential care services; social work services without accommodation }\end{array}$ \\
\hline 59 & R90-R92 & $\begin{array}{l}\text { Yaratıcı sanatlar, gösteri sanatları ve eğlence hizmetleri; kütüphane, } \\
\text { arşiv, müze ve diğer kültürel hizmetler; kumar ve müşterek bahis } \\
\text { hizmetleri } \\
\text { Creative, arts, entertainment, library, archive, museum, other cultural } \\
\text { services; gambling and betting services }\end{array}$ \\
\hline 60 & R93 & $\begin{array}{l}\text { Spor hizmetleri ile eğlence ve dinlence hizmetleri } \\
\text { Sporting services and amusement and recreation services }\end{array}$ \\
\hline 61 & $S 94$ & $\begin{array}{l}\text { Üye olunan kuruluşlar tarafından verilen hizmetler } \\
\text { Services furnished by membership organisations }\end{array}$ \\
\hline 62 & $S 95$ & $\begin{array}{l}\text { Bilgisayarların, kişisel eşyaların ve ev eşyalarının onarımına ilişkin } \\
\text { hizmetler } \\
\text { Repair services of computers and personal and household goods }\end{array}$ \\
\hline 63 & S96 & $\begin{array}{l}\text { Diğer kişisel hizmetler } \\
\text { Other personal services }\end{array}$ \\
\hline 64 & T & $\begin{array}{l}\text { Ev içi çalışan personelin işverenleri olarak hanehalklarının hizmetleri } \\
\text { Services of households as employers; undifferentiated goods and services } \\
\text { produced by households for own use }\end{array}$ \\
\hline
\end{tabular}

